\title{
Mortality among aircraft manufacturing workers
}

\author{
John D Boice Jr, Donald E Marano, Jon P Fryzek, Christopher J Sadler, \\ Joseph K McLaughlin
}

\begin{abstract}
Objectives-To evaluate the risk of cancer and other diseases among workers engaged in aircraft manufacturing and potentially exposed to compounds containing chromate, trichloroethylene (TCE), perchloroethylene (PCE), and mixed solvents.

Methods-A retrospective cohort mortality study was conducted of workers employed for at least 1 year at a large aircraft manufacturing facility in California on or after 1 January 1960. The mortality experience of these workers was determined by examination of national, state, and company records to the end of 1996. Standardised mortality ratios (SMRs) were evaluated comparing the observed numbers of deaths among workers with those expected in the general population adjusting for age, sex, race, and calendar year. The SMRs for 40 cause of death categories were computed for the total cohort and for subgroups defined by sex, race, position in the factory, work duration, year of first employment, latency, and broad occupational groups. Factory job titles were classified as to likely use of chemicals, and internal Poisson regression analyses were used to compute mortality risk ratios for categories of years of exposure to chromate, TCE, PCE, and mixed solvents, with unexposed
\end{abstract} factory workers serving as referents.

Results-The study cohort comprised 77965 workers who accrued nearly 1.9 million person-years of follow up (mean 24.2 years). Mortality follow up, estimated as $99 \%$ complete, showed that 20236 workers had died by 31 December 1996, with cause of death obtained for $98 \%$. Workers experienced low overall mortality (all causes of death SMR 0.83) and low cancer mortality (SMR 0.90). No significant increases in risk were found for any of the 40 specific cause of death categories, whereas for several causes the numbers of deaths were significantly below expectation. Analyses by occupational group and specific job titles showed no remarkable mortality patterns. Factory workers estimated to have been routinely exposed to chromate were not at increased risk of total cancer (SMR 0.93) or of lung cancer (SMR 1.02). Workers routinely exposed to TCE, PCE, or a mixture of solvents also were not at increased risk of total cancer (SMRs 0.86, 1.07, and 0.89, respectively), and the numbers of deaths for specific cancer sites were close to expected values. Slight to moderately increased rates of non-Hodgkin's lymphoma were found among workers exposed to TCE or PCE, but none was significant. A significant increase in testicular cancer was found among those with exposure to mixed solvents, but the excess was based on only six deaths and could not be linked to any particular solvent or job activity. Internal cohort analyses showed no significant trends of increased risk for any cancer with increasing years of exposure to chromate or solvents.

Conclusions-The results from this large scale cohort study of workers followed up for over 3 decades provide no clear evidence that occupational exposures at the aircraft manufacturing factory resulted in increases in the risk of death from cancer or other diseases. Our findings support previous studies of aircraft workers in which cancer risks were generally at or below expected levels.

(Occup Environ Med 1999;56:581-597)

Keywords: aircraft workers; cancer; mortality; trichloroethylene; perchloroethylene; chromate; solvents

Aircraft manufacturing took place at Lockheed Martin's Burbank California factories for 6 decades beginning in 1928. The factories were used to assemble and develop conventional military aircraft such as the F-104 Starfighter, highly classified aircraft-such as the U-2 spy plane - and commercial aircraft - such as the L1011. Classified research and development was conducted by Lockheed Advanced Development Projects, commonly known as the Lockheed Martin Skunk Works. Some of the activities required the use of chemical and physical substances - such as compounds containing chromate in painting and corrosion protection of metals, and trichloroethylene (TCE), perchloroethylene (PCE), and other solvents to dissolve grease and oil. Because some of these substances are known or suspected carcinogens, an investigation was initiated to evaluate cancer and other diseases among the aircraft workers. We present results from the mortality follow up.

\section{Methods}

COHORT DEFINITION

The study cohort comprised all workers who were employed on or after 1 January 1960 for at least 1 year at the Lockheed Martin aircraft manufacturing factories in California. Workers employed for $<1$ year were excluded. Three overlapping sources were used to identify the worker population: work history (Kardex) 
cards, personnel files, and retirement records. Available information on the work history cards, copied for nearly 100000 workers, included name, social security number, employee number, date first employed, date of birth, a complete history of jobs (occupational title, occupational code, department, plant, date of job change, date job finished), and previous employment information. Also, detailed personnel listings were available for three calendar periods ending in 1972, 1975, and 1997. Each listing included all active workers and those who finished employment sometime during the previous 10 years. Social security number, occupational code and title, department, building, date first employed, date job finished, and address on over 100000 workers were available from the personnel listings. From the company's retirement services, computerised records were available since the 1980s and included all active and retired workers receiving benefits or their spouses if the worker had died. Information in the retirement files included name, date of birth, social security number, employee number, date first employed, date job finished, date of death, last address, last occupational code, and transfer information. The overlapping sources identified 113204 workers. People who worked <1 year (33 687) and people with missing work histories (1182) or incorrect dates (370) were excluded. Short term workers are common in aircraft manufacturing, they are employed as temporary workers for specific tasks, not employed after probationary periods, and are laid oV after production runs. The final study population consisted of 77965 workers who were employed for at least 1 year on or after 1 January 1960.

DETERMINATION OF VITAL STATUS

Vital status on 31 December 1996 was sought for all workers. Mortality was determined from the California death tapes (1960-96), the National Death Index (1979-96), Pension Benefit Information Files, the Social Security Death Index, the Health Care Financing Administration beneficiary files, the California Department of Motor Vehicles registration records, employment work history cards, pension and retirement records, and obituary notices in the company newspaper from 196096. Cause of death, coded according to the international classification of diseases (ICD) code in use at the time of death, was obtained from the California death tape for those dying in California after 1959 and from the national death index for non-California residents dying after 1978. For all other deaths, death certificates were obtained from company sources or state vital statistics departments and then coded by a trained nosologist for the underlying cause of death. Of the 20236 deaths, 342 $(1.7 \%)$ had a missing cause of death.

Sources to confirm vital status included company employment and retirement records, Health Care Financing Administration files for study subjects over the age of 65, and the California Department of Motor Vehicles. Cohort members not confirmed as alive by these sources were assumed to be alive if the various mortality sources failed to indicate death. To determine the validity of this assumption, we intensely studied a random sample of 700 $(6.1 \%)$ of the 11533 workers not identified in the mortality searches or confirmed alive from the vital status sources. The approach to confirm vital status for this sample included linkages with credit bureaux, motor vehicle bureaux, phone directory assistance, voter registration lists, and property tax records. Vital status was confirmed as alive for $95 \%$ of the sample; the remaining $5 \%$ could not be found. Thus, we estimate that the number of workers lost to follow up was about 577 (5\% of 11533 ) or about $0.7 \%$ of the 77965 workers in the study cohort.

\section{ASSESSMENT OF EXPOSURES}

The approach to assess exposure to chromate, TCE, PCE, and mixed solvents is summarised briefly. Walkthrough surveys were conducted of the factories that had been closed and of similar company plants in California and Georgia to where activities and equipment had been transferred; over 50 long term employees (both retired and active) were interviewed; and existing industrial hygiene files, job descriptions going back to the $1940 \mathrm{~s}$, and other historical documents were reviewed. Also, job code and title combinations were obtained from personnel records, and job changes ( job code, date, department, plant) were abstracted from the work history cards of factory workers. From this information we identified job families (groups of occupations with similar work activities) and job titles with potential for the exposure of interest, and duration of exposure. Individual workers were then classified into categories of routine, intermittent, or no likely exposure to chromate, TCE, PCE and mixed solvents, and the duration of exposure to each substance was determined. In general, workers classified in the routine exposure jobs would be potentially exposed to the chemical of interest as a normal part of their daily activities, while workers in the intermittent category would only be exposed during particular shop runs or when assisting other workers during busy periods.

Industrial hygiene walkthrough inspections were conducted to become familiar with the manufacturing processes and patterns of use of chemicals. Walkthrough inspections of existing factories were conducted with knowledgeable former Burbank employees who were able to point out locations of departments and equipment lines as well as provide general descriptions of activities that took place in each place. The patterns of exposure to solvents and chemicals would be influenced by the type and number of aircraft being manufactured during particular calendar years. Information on the patterns of use of chemicals by job title was also obtained from historical job descriptions available as far back as 1945, from historical industrial hygiene surveys conducted as early as 1974, and from personnel interviews.

The Burbank factories consisted of four major plants, over 200 buildings, and a 
changing workforce over 60 years of operation that approached 30000 employees during peak times. Among factory workers, 784 unique job code and job title combinations were identified and classified into exposure categories. Consideration was given to applying a subjective multiplying factor to account for changing levels of exposures due to increasing use of respiratory protection and mechanical ventilation and other engineering controls to reduce exposure of the workers over the years. Although anecdotal information was obtained in the interviews with long term employees to support this concept, few actual analytical data were available to construct a meaningful multiplier. The absence of historical air sampling information before the 1970 s also limited our ability to assign meaningful exposure levels to individual workers. Thus we classified exposure on a relative scale, assuming that workers who worked routinely (daily) with specific chemicals received more cumulative exposure than those with less frequent exposure possibilities. The primary exposure metric of each worker was then taken as a measure of the specific jobs with exposure potential and the duration of time in these jobs.

Routine exposure to compounds containing chromate occurred primarily while operating process equipment in lines of tanks used for plating or to protect metals from corrosion, or when using chromate based primers or paints. The primary organic solvent used in vapour degreasers until 1966 was TCE, when it was replaced by PCE. These chemicals were not generally used as wipe solvents at Lockheed Martin factories. Jobs with exposure to TCE or PCE on a routine basis included process equipment operator and helper, electroplater, metal bond assembler, heat treater, and sheet metal forming jobs - such as drop hammer operator, straightening press operator and stretch wrap forming machine operator. It was common for workers to be exposed to many substances. For example, over $70 \%$ of workers who used TCE or PCE either routinely or intermittently were also estimated to have had exposure to compounds containing chromate on a routine or intermittent basis.

As well as TCE and PCE, a wide variety of solvents were used, including methyl ethyl ketone, alcohols, petroleum distillates, 1,1,1trichloroethane, methylene chloride, methyl isobutyl ketone, acetone, toluene, xylene, and various freons. Due to the large variety of solvents used and the changing pattern of use through the years, an exposure classification was created called mixed solvent exposures. Job titles were placed into categories depending on the potential for the person to have exposure to one or more solvents. Just over $72 \%$ of factory workers held jobs with routine or intermittent exposure to mixed solvents.

Cutting fluids and lubricants were used heavily throughout the years in the various machine shops. In the early years, these were oil based fluids, with a switch to water based fluids occurring in the mid-1970s until the early 1980s. Materials containing asbestos were used on some aircraft-such as the SR-71-and asbestos was found in several locations throughout the shops in thermal system insulation and in other building materials. The number of workers potentially exposed to asbestos was small (1231).

\section{ANALYTICAL METHODS}

Observed numbers of deaths from cancers and all other diseases were determined by race, sex, age, and calendar year for workers overall and for many subgroups defined by calendar year of employment, duration of employment, latency, occupational family, job title, and potential for chemical exposure. Expected numbers of deaths for the cohort were computed based on race, age, calendar year, and sex specific rates in the general population of California for white workers. General population rates of the United States were used for the smaller number of non-white workers because their racial composition was more similar to that of the United States than that of the state of California. The non-white workers in our cohort were predominantly African Americans, similar to the non-white United States population, whereas in California there is a much higher proportion of Asian Americans among the non-white general population.

Ratios of observed to expected deaths (or standardised mortality ratios, SMRs) were computed to determine whether the mortality experience of workers diVered from that of the general population. All 95\% confidence intervals (95\% CIs) were computed with exact methods assuming that the observed number of deaths had a Poisson distribution. The OCMAP computer program was used to calculate SMRs and 95\% CIs. ${ }^{1}$ Person-years of follow up began 1 year after the date of hire or 1 January 1960 depending on which came later. Person-years stopped at the date of death, 31 December 1996, or age 95, whichever came first. The SMRs were calculated for total mortality and for 40 specific causes of death. For family, occupation, and substance analyses, the person-years at risk would begin when first employed in a specific family, when first employed in a specific occupation, or when first exposed to a specific substance if these occurred after 1960.

To account for the favourable mortality experience, primarily for cardiovascular disease, found among newly hired workers, analyses were also conducted excluding the first 10 years of follow up after date of first employment (data not shown). Because there were few diVerences in the SMRs for cancer, the primary outcome of interest, the tables in this paper include all follow up periods. Thus, these tables can be compared directly with those in the previous studies of aircraft workers which did not exclude follow up periods in their published tables. $^{2-4}$

As well as calculations of SMRs, internal comparisons were made to assess risk within the cohort by duration of employment in specific jobs with potential for exposures of interest. Use of an internal comparison would be expected to minimise any biases that might exist when comparisons with the general 
Table 1 Number of Lockheed Martin aircraft manufacturer workers employed since 1960 for at least 1 year by demographic and occupational characteristics

\begin{tabular}{|c|c|c|c|c|c|c|}
\hline \multirow[b]{2}{*}{ Characteristic } & \multicolumn{2}{|l|}{ Factory } & \multicolumn{2}{|c|}{ Non-factory ${ }^{\star}$} & \multicolumn{2}{|l|}{ Total } \\
\hline & $n$ & $\%$ & $n$ & $\%$ & $n$ & $\%$ \\
\hline \multicolumn{7}{|l|}{ Sex: } \\
\hline Women & 6035 & 13.3 & 9453 & 29.0 & 15488 & 19.9 \\
\hline Men & 39288 & 86.7 & 23189 & 71.0 & 62477 & 80.1 \\
\hline \multicolumn{7}{|l|}{ Race: } \\
\hline White & 40013 & 88.3 & 30721 & 94.1 & 70734 & 90.7 \\
\hline Non-white & 5310 & 11.7 & 1921 & 5.9 & 7231 & 9.3 \\
\hline \multicolumn{7}{|l|}{ Year of birth: } \\
\hline$<1910$ & 4813 & 10.6 & 1752 & 5.4 & 6565 & 8.4 \\
\hline $1910-19$ & 8143 & 18.0 & 4350 & 13.3 & 12493 & 16.0 \\
\hline $1920-29$ & 8016 & 17.7 & 5804 & 17.8 & 13820 & 17.7 \\
\hline $1930-39$ & 7239 & 16.0 & 6351 & 19.5 & 13590 & 17.4 \\
\hline $1940-49$ & 9142 & 20.2 & 7526 & 23.1 & 16668 & 21.4 \\
\hline$\geqslant 1950$ & 7970 & 17.6 & 6859 & 21.0 & 14829 & 19.0 \\
\hline \multicolumn{7}{|l|}{ Year work started: } \\
\hline$<1950$ & 8290 & 18.3 & 2859 & 8.8 & 11149 & 14.3 \\
\hline $1950-59$ & 7947 & 17.5 & 5318 & 16.3 & 13265 & 17.0 \\
\hline $1960-69$ & 10777 & 23.8 & 11489 & 35.2 & 22266 & 28.6 \\
\hline $1970-79$ & 13368 & 29.5 & 5220 & 16.0 & 18588 & 23.8 \\
\hline$\geqslant 1980$ & 4941 & 10.9 & 7756 & 23.8 & 12697 & 16.3 \\
\hline \multicolumn{7}{|l|}{ Year work ended: } \\
\hline $1960-69$ & 9640 & 21.3 & 5869 & 18.0 & 15509 & 19.9 \\
\hline $1970-79$ & 15400 & 34.0 & 9529 & 29.2 & 24929 & 32.0 \\
\hline $1980-89$ & 12814 & 28.3 & 7531 & 23.1 & 20345 & 26.1 \\
\hline$\geqslant 1990$ & 4767 & 10.5 & 6308 & 19.3 & 11075 & 14.2 \\
\hline Active $(12 / 31 / 96)$ & 2702 & 6.0 & 3405 & 10.4 & 6107 & 7.8 \\
\hline \multicolumn{7}{|c|}{ Duration of employment (y): } \\
\hline $1-4$ & 13260 & 29.3 & 11394 & 34.9 & 24654 & 31.6 \\
\hline $5-9$ & 7047 & 15.6 & 5391 & 16.5 & 12438 & 16.0 \\
\hline $10-19$ & 9925 & 21.9 & 7693 & 23.6 & 17618 & 22.0 \\
\hline $20-29$ & 7798 & 17.2 & 4630 & 14.2 & 12428 & 15.9 \\
\hline $30-39$ & 6042 & 13.3 & 3109 & 9.5 & 9151 & 11.7 \\
\hline$\geqslant 40$ & 1251 & 2.8 & 425 & 1.3 & 1676 & 2.2 \\
\hline \multicolumn{7}{|c|}{ Vital status (31 December 1996): } \\
\hline Dead & 13868 & 30.6 & 6368 & 19.5 & 20236 & 26.0 \\
\hline Assumed alive & 31455 & 69.4 & 26274 & 80.5 & 57729 & 74.0 \\
\hline Total workers & 45323 & 100.0 & 32642 & 100.0 & 77965 & 100.0 \\
\hline Person-years of follow up & 1121639 & & 768156 & & 1889795 & \\
\hline
\end{tabular}

${ }^{\star} \mathrm{OY}$ ce, technical, administrative, scientific, and engineering personnel.

Table 2 Number of Lockheed Martin workers in aircraft manufacturing since 1960 for at least 1 year by various occupational characteristics and sex

\begin{tabular}{|c|c|c|c|c|c|c|}
\hline Characteristic & Women & $\%$ & Men & $\%$ & Total & $\%$ \\
\hline Total factory workers: & 6035 & 100.0 & 39288 & 100.0 & 45323 & 100.0 \\
\hline \multicolumn{7}{|l|}{ Factory family (ever):* } \\
\hline Assembly & 2625 & 43.5 & 21670 & 55.2 & 24295 & 53.6 \\
\hline Fabrication & 1167 & 19.3 & 9837 & 25.0 & 11004 & 24.3 \\
\hline Maintenance & 300 & 5.0 & 3853 & 9.8 & 4153 & 9.2 \\
\hline Research and development & 101 & 1.7 & 4923 & 12.5 & 5024 & 11.1 \\
\hline Electrical or electronics & 2748 & 45.5 & 6266 & 16.0 & 9014 & 19.9 \\
\hline Machine shop & 491 & 8.2 & 7536 & 19.2 & 8027 & 17.7 \\
\hline Tooling & 167 & 2.8 & 5793 & 14.7 & 5960 & 13.2 \\
\hline Processing & 407 & 6.7 & 2818 & 7.2 & 3225 & 7.1 \\
\hline Quality assurance & 470 & 7.8 & 3529 & 9.0 & 3999 & 8.8 \\
\hline Other & 457 & 7.6 & 2726 & 6.9 & 3183 & 7.0 \\
\hline \multicolumn{7}{|l|}{ Specific occupations (ever): ${ }^{\star}$} \\
\hline Painter & 77 & 1.3 & 1139 & 2.9 & 1216 & 2.7 \\
\hline Plater & 22 & 0.4 & 164 & 0.4 & 186 & 0.4 \\
\hline Process operator & 295 & 4.9 & 1145 & 2.9 & 1440 & 3.2 \\
\hline Plastic parts fabricator & 412 & 6.8 & 2269 & 5.8 & 2681 & 5.9 \\
\hline Welder & 36 & 0.6 & 774 & 2.0 & 810 & 1.8 \\
\hline Metal bonder & 116 & 1.9 & 1046 & 2.7 & 1162 & 2.6 \\
\hline Final assembler & 2304 & 38.2 & 18594 & 47.3 & 20898 & 46.1 \\
\hline $\begin{array}{c}\text { Fabrication and structures } \\
\text { development mechanic }\end{array}$ & 24 & 0.4 & 2401 & 6.1 & 2425 & 5.4 \\
\hline \multicolumn{7}{|l|}{ Specific exposure potential: ${ }^{\star}$} \\
\hline \multicolumn{7}{|l|}{ Chromate: } \\
\hline Intermittent & 272 & 4.5 & 3537 & 9.0 & 3809 & 8.4 \\
\hline Routine & 467 & 7.7 & 3167 & 8.1 & 3634 & 8.0 \\
\hline \multicolumn{7}{|l|}{ Trichloroethylene: } \\
\hline Intermittent & 160 & 2.7 & 3016 & 7.7 & 3176 & 7.0 \\
\hline Routine & 192 & 3.2 & 2075 & 5.3 & 2267 & 5.0 \\
\hline \multicolumn{7}{|l|}{ Perchloroethylene: } \\
\hline Intermittent & 141 & 2.3 & 3058 & 7.8 & 3199 & 7.1 \\
\hline Routine & 383 & 6.3 & 2248 & 5.7 & 2631 & 5.8 \\
\hline \multicolumn{7}{|l|}{ Mixed solvents: } \\
\hline Intermittent & 2440 & 40.4 & 21099 & 53.7 & 23539 & 51.9 \\
\hline Routine & 970 & 16.1 & 8231 & 21.0 & 9201 & 20.3 \\
\hline Cutting oils & 414 & 6.9 & 7646 & 19.5 & 8060 & 17.8 \\
\hline Asbestos & 236 & 3.9 & 995 & 2.5 & 1231 & 2.7 \\
\hline
\end{tabular}

*Workers could be in more than one family, occupation, or exposure category. population are made. Relative risks were estimated by Poisson regression techniques with trend tests conducted to learn whether there were significant increases in risk with increasing years of potential exposure to specific chemicals. ${ }^{5}$ The regression model computed relative risks over four categories of years of potential exposure $(0,<1,1-4, \geqslant 5$ years), excluding the small percentage with unknown years of exposure. For all analyses, the non-exposed referent category consisted of 11097 factory workers who had no or only incidental exposure to solvents or chromate. Date of birth, date of starting employment, date of finishing employment, sex and race (white or non-white) were included in the model.

The internal comparisons relied on the detailed information available from work histories, and the time spent in each occupation associated with particular exposures was computed for each person. Only employees with work history (Kardex) information were included in these analyses as detailed occupational histories were not available from general personnel or retirement files. Finally, because non-factory workers seemed to diVer appreciably from factory workers, the internal comparisons were based only on factory workers. Guided by published reports, ${ }^{34-9}$ internal analyses focused on cancers of the oesophagus, lung, liver, kidney, prostate, breast, ovary, multiple myeloma, non-Hodgkin's lymphoma, leukaemia, and total cancer.

\section{Results}

DESCRIPTIVE STATISTICS ON THE WORKER POPULATION

Among the 77965 workers employed on or after 1960 for at least 1 year, $80.1 \%$ were male, $90.7 \%$ were white, $42.1 \%$ were born before $1930,14.3 \%$ were first employed before 1950 , $19.9 \%$ finished working in the 1960 s, $29.8 \%$ were employed for $\geqslant 20$ years, and $26.0 \%$ had died (table 1). Nearly $42 \%$ of the workers were employed in non-factory positions - such as administration (26\%), oY ce and technology $(38 \%)$, and science and engineering (36\%). Among the 45323 factory workers, $53.6 \%$ had held at least one position in assembly, $24.3 \%$ in fabrication, $19.9 \%$ in electrical or electronics, $17.7 \%$ in the machine shop, $13.2 \%$ in tooling, and $11.1 \%$ in research and development (table 2).

Many factory workers had the potential for routine exposure to agents of interest: chromate $(3634$ or $8.0 \%)$, TCE (2267 or $5.0 \%$ ), PCE (2631 or $5.8 \%$ ), and mixed solvents (9201 or $20.3 \%$ ). Additional factory workers had the potential for intermittent exposure: chromate (3809 or $8.4 \%$ ), TCE (3176 or $7.0 \%$ ), PCE (3199 or $7.1 \%$ ), and mixed solvents (23 539 or $51.9 \%$ ). There were 8060 or $17.8 \%$ of the employees exposed to cutting oils. Only 1231 or $2.7 \%$ of the factory workers were estimated to have worked with asbestos (table 2). 
OVERALL MORTALITY

Overall, 1889795 person-years of follow up were accumulated for an average of 24.2 years per worker (table 3). There were 20236 deaths observed against 24306.0 expected (SMR 0.83 ; $95 \%$ CI 0.82 to 0.84 ). This $17 \%$ lower risk of all cause mortality was attributed to significant reductions in heart, cerebrovascular, and non-malignant respiratory diseases, and all external causes. Mortality from all cancers was also significantly less than expected (SMR $0.90 ; 95 \%$ CI 0.88 to 0.92 ; observed 5468). Other causes of death that occurred significantly below expectation included diabetes and cirrhosis of the liver. No cause of death was significantly increased. Proportional distribution of the 342 deaths for which cause of death was missing over the 40 specific cause of death categories had a trivial eVect on the SMRs.

NON-FACTORY WORKERS

The 32642 non-factory workers had lower risks of death than factory workers for most causes (table 3). Cancer rates were lower in large part because of a significantly low risk of lung cancer (SMR 0.71) compared with a near expected risk among factory workers (SMR 0.97). Mortality from other cancers strongly related to smoking (oral cavity, oesophagus, larynx, and bladder) was also lower among non-factory (SMR 0.79) than factory workers (SMR 0.85), whereas mortality from all other cancers was similar (SMRs 0.93 and 0.91, respectively). Emphysema was lower among non-factory workers (SMR 0.70) than factory (SMR 0.82) workers, and significant deficits of liver cirrhosis were found in both factory and non-factory workers.

The analyses and tables described later relate to factory workers employed for at least 1 year.

SEX AND RACE

There were few diVerences in mortality patterns among factory workers by sex or race (data not presented). The SMRs for total mortality were nearly identical among men (SMR $0.87 ; 95 \%$ CI 0.85 to 0.88 ) and women (SMR $0.88 ; 95 \%$ CI 0.84 to 0.93 ), and among white (SMR $0.87 ; 95 \%$ CI 0.86 to 0.89 ) and non-white workers (SMR 0.87; 95\% CI 0.82 to 0.92). The total cancer mortality ratio was lower among white (SMR 0.92; 95\% CI 0.89 to 0.95 ) than non-white workers (SMR 1.08; $95 \%$ CI 0.97 to 1.19 ), as was the mortality ratio from all external causes: SMRs $0.73(95 \%$ CI 0.68 to 0.78 ) and 0.92 (95\% CI 0.78 to 1.07), respectively. Non-white women had a significantly high rate of breast cancer (SMR

Table 3 Standardised mortality ratios for Lockheed Martin factory and non-factory workers employed in aircraft manufacturing for at least 1 year since 1960 and followed up to the end of 1996 (sex and race combined)

\begin{tabular}{|c|c|c|c|c|c|c|c|c|c|c|}
\hline \multirow[b]{2}{*}{ Cause of death (ICD-9) } & \multicolumn{3}{|c|}{$\begin{array}{l}\text { Factory workers } \\
1121639 \text { person-years }\end{array}$} & \multicolumn{3}{|c|}{$\begin{array}{l}\text { Non-factory workers } \\
768156 \text { person-years }\end{array}$} & \multicolumn{3}{|c|}{$\begin{array}{l}\text { Total workers } \\
1889795 \text { person-years }\end{array}$} & \multirow[b]{2}{*}{$95 \% C I$} \\
\hline & $O b s$ & $\operatorname{Exp}$ & $S M R$ & Obs & $\operatorname{Exp}$ & $S M R$ & Obs & $\operatorname{Exp}$ & $S M R$ & \\
\hline All causes of death (001-999) & 13868 & 15944.4 & $0.87^{\star}$ & 6368 & 8361.6 & $0.76^{\star}$ & 20236 & 24306.0 & $0.83^{\star}$ & 0.82 to 0.84 \\
\hline All malignant neoplasms (140-208) & 3636 & 3891.1 & $0.94^{\star}$ & 1832 & 2184.8 & $0.84^{\star}$ & 5468 & 6075.9 & $0.90^{\star}$ & 0.88 to 0.92 \\
\hline Buccal cavity and pharynx $(140-149)$ & 63 & 101.5 & $0.62^{\star}$ & 38 & 54.4 & $0.70^{\star}$ & 101 & 156.0 & $0.65^{\star}$ & 0.53 to 0.79 \\
\hline Oesophagus (150) & 98 & 101.5 & 0.97 & 48 & 51.8 & 0.93 & 146 & 153.3 & 0.95 & 0.80 to 1.12 \\
\hline Stomach (151) & 110 & 149.1 & $0.74^{\star}$ & 52 & 75.7 & $0.69^{\star}$ & 162 & 224.8 & $0.72^{\star}$ & 0.61 to 0.84 \\
\hline Colon (153) & 334 & 330.6 & 1.01 & 170 & 179.6 & 0.95 & 504 & 510.2 & 0.99 & 0.90 to 1.08 \\
\hline Rectum (154) & 72 & 81.1 & 0.89 & 30 & 43.3 & $0.69^{\star}$ & 102 & 124.4 & 0.82 & 0.67 to 1.00 \\
\hline Biliary passages and liver $(155,156)$ & 86 & 91.5 & 0.94 & 41 & 51.0 & 0.80 & 127 & 142.5 & 0.89 & 0.74 to 1.06 \\
\hline Pancreas (157) & 177 & 203.6 & 0.87 & 107 & 112.3 & 0.95 & 284 & 315.9 & 0.90 & 0.80 to 1.01 \\
\hline Larynx (161) & 36 & 43.0 & 0.84 & 15 & 21.9 & 0.69 & 51 & 64.9 & 0.79 & 0.59 to 1.03 \\
\hline Bronchus, trachea, and lung (162) & 1196 & 1231.2 & 0.97 & 487 & 681.7 & $0.71^{\star}$ & 1683 & 1912.9 & $0.88^{\star}$ & 0.84 to 0.92 \\
\hline Bone $(170)$ & 6 & 8.8 & 0.68 & 4 & 4.8 & 0.83 & 10 & 13.6 & 0.74 & 0.35 to 1.35 \\
\hline Connective tissue (171) & 19 & 21.1 & 0.90 & 13 & 13.0 & 1.00 & 32 & 34.2 & 0.94 & 0.64 to 1.32 \\
\hline Melanoma of skin (172) & 42 & 60.0 & $0.70^{\star}$ & 43 & 38.8 & 1.11 & 85 & 98.8 & 0.86 & 0.69 to 1.06 \\
\hline Breast $(174,175)$ & 99 & 94.2 & 1.05 & 103 & 97.4 & 1.06 & 202 & 191.6 & 1.05 & 0.91 to 1.21 \\
\hline All uterine (women only) (179-182) & 19 & 26.8 & 0.71 & 21 & 24.3 & 0.87 & 40 & 51.1 & 0.78 & 0.56 to 1.07 \\
\hline Cervix uteri (women only) (180) & 9 & 12.7 & 0.71 & 8 & 12.4 & 0.65 & 17 & 25.1 & 0.68 & 0.39 to 1.08 \\
\hline Ovary (women only) (183) & 30 & 29.0 & 1.03 & 34 & 29.4 & 1.15 & 64 & 58.5 & 1.10 & 0.84 to 1.40 \\
\hline Prostate (men only) (185) & 359 & 331.6 & 1.08 & 127 & 150.1 & 0.85 & 486 & 481.6 & 1.00 & 0.92 to 1.10 \\
\hline Testis and other male genital $(186,187)$ & 15 & 9.8 & 1.53 & 1 & 5.3 & 0.19 & 16 & 15.1 & 1.06 & 0.61 to 1.72 \\
\hline Kidney $(189.0-189.2)$ & 75 & 87.0 & 0.86 & 50 & 49.5 & 1.01 & 125 & 136.5 & 0.92 & 0.76 to 1.09 \\
\hline \multicolumn{11}{|l|}{ Bladder and other urinary } \\
\hline$(188,189.3-189.9)$ & 97 & 100.5 & 0.97 & 39 & 49.8 & 0.78 & 136 & 150.3 & 0.90 & 0.76 to 1.07 \\
\hline Brain and CNS (191-192) & 69 & 98.8 & $0.70^{\star}$ & 62 & 61.6 & 1.01 & 131 & 160.4 & $0.82^{\star}$ & 0.68 to 0.97 \\
\hline Non-Hodgkin's lymphoma $(200,202)$ & 137 & 146.2 & 0.94 & 78 & 85.0 & 0.92 & 215 & 231.8 & 0.93 & 0.81 to 1.06 \\
\hline Hodgkin's disease (201) & 17 & 19.0 & 0.89 & 11 & 11.1 & 0.99 & 28 & 30.1 & 0.93 & 0.62 to 1.34 \\
\hline Multiple myeloma (203) & 90 & 76.7 & 1.17 & 29 & 40.2 & 0.72 & 119 & 117.3 & 1.01 & 0.84 to 1.21 \\
\hline Leukaemia and aleukaemia (204-208) & 146 & 139.2 & 1.05 & 75 & 78.1 & 0.96 & 221 & 217.3 & 1.02 & 0.89 to 1.16 \\
\hline Diabetes $(250)$ & 200 & 240.4 & $0.83^{\star}$ & 82 & 129.4 & $0.63^{\star}$ & 282 & 369.8 & $0.76^{\star}$ & 0.68 to 0.86 \\
\hline \multicolumn{11}{|l|}{ All heart disease $(390-398,402,404$, } \\
\hline $410-429)$ & 5129 & 5742.6 & $0.89^{\star}$ & 2271 & 2868.6 & $0.79^{\star}$ & 7400 & 8611.1 & $0.86^{\star}$ & 0.84 to 0.88 \\
\hline Cerebrovascular disease $(430-438)$ & 832 & 990.0 & $0.84^{\star}$ & 382 & 472.9 & $0.81^{\star}$ & 1214 & 1462.9 & $0.83^{\star}$ & 0.78 to 0.88 \\
\hline Non-malignant respiratory $(460-519)$ & 1032 & 1330.4 & $0.78^{\star}$ & 460 & 676.5 & $0.68^{\star}$ & 1492 & 2006.9 & $0.74^{\star}$ & 0.71 to 0.78 \\
\hline Emphysema (492) & 177 & 215.7 & $0.82^{\star}$ & 75 & 107.1 & $0.70^{\star}$ & 252 & 322.8 & $0.78^{\star}$ & 0.69 to 0.88 \\
\hline Asthma (493) & 22 & 28.3 & 0.77 & 13 & 16.4 & 0.80 & 35 & 44.7 & 0.78 & 0.55 to 1.09 \\
\hline Cirrhosis of liver (571) & 324 & 507.3 & $0.64^{\star}$ & 157 & 300.0 & $0.52^{\star}$ & 481 & 807.3 & $0.60^{\star}$ & 0.54 to 0.65 \\
\hline Nephritis and nephrosis $(580-589)$ & 94 & 95.9 & 0.98 & 43 & 45.1 & 0.95 & 137 & 141.0 & 0.97 & 0.82 to 1.15 \\
\hline All external causes $(800-999)$ : & 971 & 1281.9 & $0.76^{\star}$ & 371 & 716.5 & $0.52^{\star}$ & 1342 & 1998.4 & $0.67^{\star}$ & 0.63 to 0.71 \\
\hline Accidents (850-949) & 572 & 748.4 & $0.76^{\star}$ & 219 & 414.6 & $0.53^{\star}$ & 791 & 1163.0 & $0.68^{\star}$ & 0.63 to 0.73 \\
\hline Suicides (950-959) & 257 & 341.0 & $0.75^{\star}$ & 123 & 206.9 & $0.60^{\star}$ & 380 & 547.8 & $0.69^{\star}$ & 0.63 to 0.77 \\
\hline Unknown cause of death & 218 & & & 124 & & & 342 & & & \\
\hline
\end{tabular}

${ }^{\star} \mathrm{p}<0.05$. 
$1.82 ; 95 \%$ CI 1.10 to 2.84 ) and a significantly low rate of uterine cancer (SMR 0.00; 95\% CI 0.00 to 0.76 ). For white workers the numbers of breast (SMR 0.96; 95\% CI 0.76 to 1.19 ) and uterine (SMR 0.78; 95\% CI 0.45 to 1.24 ) cancers were slightly lower than expected.

\section{TIME SINCE FIRST EMPLOYMENT}

The ratios of observed to expected deaths by time after first employment reflect the favourable mortality experience of newly employed and presumably healthy people (table 4). For the intervals $<10,10-19$, and $\geqslant 20$ years after date of first employment, the all cause mortality SMRs were 0.68, 0.85, and 0.90, respectively. The reduced SMRs, especially during the initial years after first employment were due to low risks for heart disease, cerebrovascular disease, and accidents. For all cancer mortality the corresponding SMRs, 0.89, 0.96, and 0.93, varied little over time.

DURATION OF EMPLOYMENT

Variations in the risk of death by duration of employment were apparent among factory workers (table 5) with long term workers ( $\geqslant 30$ years) experiencing a lower mortality ratio (SMR 0.78) than short term workers $(<10$ years, SMR 0.94), reflecting the healthy status necessary to work for many years. Cancer risks were also lower among long term workers (SMR $0.86 v 1.05)$, due largely to diVerences in mortality from lung cancer (SMR $0.70 v$ 1.23). Workers employed for $\geqslant 30$ years had a significant excess of prostate cancer (SMR $1.24)$ and a significant deficit of kidney cancer (SMR 0.52).

CALENDAR YEAR OF FIRST EMPLOYMENT

The 8290 workers employed before 1950 who were still working in 1960 had the longest average follow up (27.6 years) and the lowest all cause SMR compared with more recently employed workers (data not presented). The all cause SMRs for calendar periods of hire $<1950,1950-59,1960-69$, and 1970-95 were $0.81(95 \%$ CI 0.79 to 0.83$), 0.89$ (95\% CI 0.87 to 0.92 ), 0.93 (95\% CI 0.90 to 0.96 ), and 0.93 ( $95 \%$ CI 0.89 to 0.97 ), respectively. For all cancers, the corresponding SMRs were 0.84 (95\% CI 0.80 to 0.89 ), 0.95 (95\% CI 0.89 to 1.01 ), 1.01 (95\% CI 0.95 to 1.09 ), and 1.08 (95\% CI 0.99 to 1.17 ), respectively. The 18309 workers hired after 1970 had the shortest average follow up (18.8 years). By 1996, slightly over $65 \%$ of the workers hired before 1950 had died, by contrast with $10 \%$ of the workers hired after 1970. The workers hired before 1950 had significantly low risks of lung cancer (SMR 0.73; 95\% CI 0.66 to 0.81 ), emphysema (SMR 0.81; 95\% CI 0.65 to 0.99 ),

Table 4 Standardised mortality ratios for Lockheed Martin factory workers employed in aircraft manufacturing for at least 1 year since 1960 and followed up to the end of 1996 by time since first hire (sex and race combined)

\begin{tabular}{|c|c|c|c|c|c|c|c|c|c|}
\hline \multirow[b]{2}{*}{ Cause of death (ICD-9) } & \multicolumn{3}{|c|}{$\begin{array}{l}<10 y \\
286365 \text { person-years }\end{array}$} & \multicolumn{3}{|c|}{$\begin{array}{l}10-19 y \\
339269 \text { person-years }\end{array}$} & \multicolumn{3}{|c|}{$\begin{array}{l}\geqslant 20 y \\
496004 \text { person-years }\end{array}$} \\
\hline & Obs & $S M R$ & $95 \% C I$ & Obs & $S M R$ & $95 \% C I$ & Obs & $S M R$ & $95 \% C I$ \\
\hline All causes of death (001-999) & 878 & $0.68^{\star}$ & 0.64 to 0.73 & 2318 & $0.85^{\star}$ & 0.81 to 0.88 & 10672 & $0.90^{\star}$ & 0.88 to 0.91 \\
\hline All malignant neoplasms (140-208) & 215 & 0.89 & 0.78 to 1.02 & 613 & 0.96 & 0.89 to 1.04 & 2808 & $0.93^{\star}$ & 0.90 to 0.97 \\
\hline Buccal cavity and pharynx $(140-149)$ & 4 & 0.49 & 0.13 to 1.26 & 15 & 0.75 & 0.42 to 1.24 & 44 & $0.60^{\star}$ & 0.44 to 0.81 \\
\hline Oesophagus $(150)$ & 6 & 0.98 & 0.36 to 2.12 & 14 & 0.79 & 0.43 to 1.33 & 78 & 1.00 & 0.79 to 1.25 \\
\hline Stomach (151) & 7 & 0.69 & 0.28 to 1.43 & 25 & 0.95 & 0.61 to 1.40 & 78 & $0.69^{\star}$ & 0.55 to 0.86 \\
\hline Colon (153) & 13 & 0.78 & 0.42 to 1.34 & 54 & 1.10 & 0.83 to 1.45 & 267 & 1.01 & 0.89 to 1.13 \\
\hline Rectum (154) & 3 & 0.58 & 0.12 to 1.69 & 8 & 0.58 & 0.25 to 1.14 & 61 & 0.98 & 0.75 to 1.26 \\
\hline Biliary passages and liver $(155,156)$ & 6 & 1.31 & 0.48 to 2.86 & 12 & 0.85 & 0.44 to 1.48 & 68 & 0.93 & 0.73 to 1.18 \\
\hline Pancreas (157) & 13 & 1.10 & 0.59 to 1.89 & 27 & 0.82 & 0.54 to 1.19 & 137 & 0.86 & 0.72 to 1.02 \\
\hline Larynx $(161)$ & 1 & 0.35 & 0.01 to 1.94 & 10 & 1.29 & 0.62 to 2.37 & 25 & 0.77 & 0.50 to 1.14 \\
\hline Bronchus, trachea, and lung (162) & 76 & 1.06 & 0.83 to 1.32 & 214 & 1.05 & 0.91 to 1.20 & 906 & 0.95 & 0.89 to 1.01 \\
\hline Bone $(170)$ & 0 & {$[1.27] \dagger$} & 0.00 to 2.91 & 1 & 0.53 & 0.01 to 2.92 & 5 & 0.89 & 0.29 to 2.07 \\
\hline Connective tissue (171) & 6 & $2.96^{\star}$ & 1.09 to 6.44 & 2 & 0.48 & 0.06 to 1.73 & 11 & 0.74 & 0.37 to 1.32 \\
\hline Melanoma of skin (172) & 3 & 0.48 & 0.10 to 1.40 & 14 & 1.11 & 0.60 to 1.85 & 25 & $0.61^{\star}$ & 0.39 to 0.90 \\
\hline Breast $(174,175)$ & 9 & 0.91 & 0.42 to 1.73 & 21 & 0.97 & 0.60 to 1.48 & 69 & 1.10 & 0.86 to 1.40 \\
\hline All uterine (women only) (179-182) & 2 & 0.71 & 0.09 to 2.56 & 6 & 0.96 & 0.35 to 2.08 & 11 & 0.62 & 0.31 to 1.12 \\
\hline Cervix uteri (women only) (180) & 1 & 0.50 & 0.01 to 2.81 & 4 & 1.04 & 0.28 to 2.67 & 4 & 0.58 & 0.16 to 1.49 \\
\hline Ovary (women only) (183) & 2 & 0.80 & 0.10 to 2.89 & 6 & 1.00 & 0.37 to 2.18 & 22 & 1.07 & 0.67 to 1.62 \\
\hline Prostate (men only) (185) & 4 & 0.63 & 0.17 to 1.61 & 27 & 0.90 & 0.59 to 1.30 & 328 & 1.11 & 0.99 to 1.24 \\
\hline Testis and other male genital $(186,187)$ & 4 & 1.29 & 0.35 to 3.31 & 5 & 1.86 & 0.60 to 4.34 & 6 & 1.49 & 0.55 to 3.24 \\
\hline Kidney $(189.0-189.2)$ & 4 & 0.73 & 0.20 to 1.86 & 16 & 1.08 & 0.62 to 1.75 & 55 & 0.83 & 0.62 to 1.08 \\
\hline Bladder and other urinary $(188,189.3-189.9)$ & 3 & 0.75 & 0.16 to 2.19 & 17 & 1.33 & 0.78 to 2.13 & 77 & 0.92 & 0.73 to 1.15 \\
\hline Brain and CNS (191-192) & 10 & 0.97 & 0.46 to 1.78 & 11 & $0.52^{\star}$ & 0.26 to 0.93 & 48 & $0.71^{\star}$ & 0.53 to 0.95 \\
\hline Non-Hodgkin's lymphoma $(200,202)$ & 8 & 0.68 & 0.29 to 1.34 & 27 & 1.04 & 0.68 to 1.51 & 102 & 0.94 & 0.77 to 1.14 \\
\hline Hodgkin's disease (201) & 2 & 0.48 & 0.06 to 1.72 & 5 & 0.98 & 0.32 to 2.29 & 10 & 1.03 & 0.49 to 1.89 \\
\hline Multiple myeloma (203) & 6 & 1.08 & 0.40 to 2.34 & 14 & 1.08 & 0.59 to 1.82 & 70 & 1.20 & 0.94 to 1.52 \\
\hline Leukaemia and aleukaemia (204-208) & 9 & 0.81 & 0.37 to 1.53 & 18 & 0.78 & 0.46 to 1.23 & 119 & 1.14 & 0.94 to 1.36 \\
\hline Diabetes $(250)$ & 1 & $0.07^{\star}$ & 0.00 to 0.37 & 19 & $0.49^{\star}$ & 0.29 to 0.76 & 180 & 0.97 & 0.83 to 1.12 \\
\hline All heart disease $(390-398,402,404,410-429)$ & 224 & $0.64^{\star}$ & 0.56 to 0.73 & 772 & $0.87^{\star}$ & 0.81 to 0.93 & 4133 & $0.92^{\star}$ & 0.89 to 0.95 \\
\hline Cerebrovascular disease $(430-438)$ & 23 & $0.47^{\star}$ & 0.30 to 0.70 & 102 & $0.77^{\star}$ & 0.63 to 0.94 & 707 & $0.87^{\star}$ & 0.81 to 0.94 \\
\hline Non-malignant respiratory $(460-519)$ & 10 & $0.19^{\star}$ & 0.09 to 0.34 & 113 & $0.73^{\star}$ & 0.60 to 0.88 & 908 & $0.81^{\star}$ & 0.76 to 0.86 \\
\hline Emphysema (492) & 3 & $0.27^{\star}$ & 0.06 to 0.78 & 29 & 0.89 & 0.60 to 1.29 & 145 & $0.84^{\star}$ & 0.71 to 0.99 \\
\hline Asthma (493) & 0 & {$[2.76] \dagger$} & 0.00 to 1.34 & 6 & 0.99 & 0.36 to 2.16 & 16 & 0.82 & 0.47 to 1.33 \\
\hline Cirrhosis of liver (571) & 33 & $0.48^{\star}$ & 0.33 to 0.67 & 90 & $0.67^{\star}$ & 0.54 to 0.82 & 201 & $0.66^{\star}$ & 0.57 to 0.76 \\
\hline Nephritis and nephrosis $(580-589)$ & 0 & {$[6.90]^{\star}+$} & 0.00 to 0.54 & 11 & 0.73 & 0.37 to 1.31 & 83 & 1.12 & 0.89 to 1.39 \\
\hline All external causes (800-999) & 264 & $0.75^{\star}$ & 0.66 to 0.85 & 301 & $0.82^{\star}$ & 0.73 to 0.91 & 406 & $0.72^{\star}$ & 0.66 to 0.80 \\
\hline Accidents (850-949) & 163 & $0.80^{\star}$ & 0.68 to 0.93 & 163 & $0.78^{\star}$ & 0.66 to 0.91 & 246 & $0.74^{\star}$ & 0.65 to 0.83 \\
\hline Suicides $(950-959)$ & 50 & $0.65^{\star}$ & 0.48 to 0.86 & 85 & 0.90 & 0.72 to 1.12 & 122 & $0.72^{\star}$ & 0.60 to 0.86 \\
\hline Unknown cause of death & 38 & & & 69 & & & 111 & & \\
\hline
\end{tabular}

${ }^{\star} \mathrm{p}<0.05$.

†Expected value. 
Table 5 Standardised mortality ratios for Lockheed Martin factory workers employed in aircraft manufacturing for at least 1 year since 1960 and followed up to the end of 1996 by duration of employment (sex and race combined)

\begin{tabular}{|c|c|c|c|c|c|c|c|c|c|c|c|c|}
\hline \multirow[b]{2}{*}{ Cause of death (ICD-9) } & \multicolumn{3}{|c|}{$\begin{array}{l}<10 \text { y } \\
559943 \text { person-years }\end{array}$} & \multicolumn{3}{|c|}{$\begin{array}{l}10-19 y \\
248167 \text { person-years }\end{array}$} & \multicolumn{3}{|c|}{$\begin{array}{l}20-29 y \\
194928 \text { person-years }\end{array}$} & \multicolumn{3}{|c|}{$\begin{array}{l}\geqslant 30 y \\
118601 \text { person-years }\end{array}$} \\
\hline & Obs & $S M R$ & $95 \% C I$ & Obs & $S M R$ & $95 \% C I$ & Obs & $S M R$ & $95 \% C I$ & Obs & $S M R$ & $95 \% C I$ \\
\hline All causes of death (001-999) & 3968 & $0.94^{\star}$ & 0.91 to 0.97 & 3270 & $90.0^{\star}$ & 0.87 to 0.94 & 3859 & $0.85^{\star}$ & 0.82 to 0.87 & 2771 & $0.78^{\star}$ & 0.75 to 0.81 \\
\hline \multicolumn{13}{|l|}{ All malignant neoplasms } \\
\hline$(140-208)$ & 1046 & 1.05 & 0.99 to 1.12 & 830 & 0.97 & 0.91 to 1.04 & 930 & $0.87^{\star}$ & 0.81 to 0.92 & 830 & $0.86^{\star}$ & 0.80 to 0.92 \\
\hline \multicolumn{13}{|l|}{ Buccal cavity and pharynx } \\
\hline Oesophagus (150) & 26 & 0.96 & 0.63 to 1.41 & 18 & 0.81 & 0.48 to 1.28 & 30 & 1.11 & 0.75 to 1.59 & 24 & 0.95 & 0.61 to 1.41 \\
\hline Stomach (151) & 35 & 0.95 & 0.66 to 1.32 & 30 & 0.87 & 0.59 to 1.24 & 20 & 0.46 & 0.28 to 0.71 & 25 & 0.74 & 0.48 to 1.09 \\
\hline Colon (153) & 84 & 1.08 & 0.87 to 1.34 & 70 & 0.96 & 0.75 to 1.22 & 88 & 0.92 & 0.74 to 1.13 & 92 & 1.09 & 0.88 to 1.33 \\
\hline Rectum (154) & 14 & 0.71 & 0.39 to 1.20 & 17 & 0.91 & 0.53 to 1.45 & 23 & 0.95 & 0.60 to 1.43 & 18 & 0.97 & 0.58 to 1.54 \\
\hline \multicolumn{13}{|l|}{ Biliary passages and liver } \\
\hline$(155,156)$ & 27 & 1.12 & 0.74 to 1.63 & 17 & 0.86 & 0.50 to 1.38 & 25 & 1.02 & 0.66 to 1.51 & 17 & 0.73 & 0.43 to 1.18 \\
\hline Pancreas (157) & 46 & 0.92 & 0.67 to 1.22 & 39 & 0.87 & 0.62 to 1.19 & 52 & 0.90 & 0.67 to 1.18 & 40 & 0.79 & 0.57 to 1.08 \\
\hline Larynx (161) & 15 & 1.34 & 0.75 to 2.21 & 4 & 0.42 & 0.12 to 1.08 & 6 & 0.51 & 0.19 to 1.10 & 11 & 1.06 & 0.53 to 1.90 \\
\hline \multicolumn{13}{|l|}{ Bronchus, trachea, and lung } \\
\hline$(162)$ & 390 & $1.23^{\star}$ & 1.11 to 1.36 & 285 & 1.08 & 0.96 to 1.22 & 297 & 0.90 & 0.80 to 1.01 & 224 & $0.70^{\star}$ & 0.61 to 0.80 \\
\hline Bone (170) & 3 & 1.05 & 0.22 to 3.06 & 1 & 0.49 & 0.01 to 2.75 & 0 & 0.00 & 0.00 to 1.58 & 2 & 1.26 & 0.15 to 4.55 \\
\hline Connective tissue (171) & 11 & 1.60 & 0.79 to 2.84 & 3 & 0.66 & 0.14 to 1.93 & 3 & 0.60 & 0.12 to 1.76 & 2 & 0.43 & 0.05 to 1.55 \\
\hline Melanoma of skin (172) & 19 & 0.88 & 0.53 to 1.38 & 9 & 0.71 & 0.32 to 1.34 & 6 & $0.45^{\star}$ & 0.17 to 0.99 & 8 & 0.64 & 0.28 to 1.26 \\
\hline Breast $(174,175)$ & 20 & 0.84 & 0.51 to 1.30 & 31 & 1.16 & 0.79 to 1.64 & 30 & 1.02 & 0.69 to 1.46 & 18 & 1.26 & 0.75 to 1.99 \\
\hline \multicolumn{13}{|l|}{ All uterine (women only) } \\
\hline$(179-182)$ & 3 & 0.49 & 0.10 to 1.44 & 6 & 0.75 & 0.27 to 1.62 & 6 & 0.68 & 0.24 to 1.47 & 4 & 1.07 & 0.29 to 2.75 \\
\hline \multicolumn{13}{|l|}{ Cervix uteri (women only) } \\
\hline$(180)$ & 1 & 0.28 & 0.01 to 1.55 & 4 & 0.98 & 0.26 to 2.50 & 3 & 0.80 & 0.17 to 2.34 & 1 & 0.78 & 0.02 to 4.34 \\
\hline Ovary (women only) (183) & 8 & 1.25 & 0.54 to 2.47 & 9 & 1.09 & 0.50 to 2.08 & 9 & 0.93 & 0.42 to 1.76 & 4 & 0.85 & 0.23 to 2.18 \\
\hline Prostate (men only) (185) & 71 & 1.08 & 0.84 to 1.36 & 78 & 1.15 & 0.91 to 1.43 & 85 & 0.88 & 0.70 to 1.08 & 125 & $1.24^{\star}$ & 1.03 to 1.48 \\
\hline \multicolumn{13}{|l|}{ Testis and other male genital } \\
\hline$(186,187)$ & 7 & 1.41 & 0.57 to 2.90 & 3 & 1.44 & 0.30 to 4.21 & 3 & 1.76 & 0.36 to 5.14 & 2 & 1.91 & 0.23 to 6.91 \\
\hline Kidney (189.0-189.2) & 19 & 0.79 & 0.48 to 1.24 & 22 & 1.17 & 0.73 to 1.77 & 23 & 1.00 & 0.63 to 1.50 & 11 & $0.52^{\star}$ & 0.26 to 0.93 \\
\hline \multicolumn{13}{|l|}{ Bladder and other urinary } \\
\hline$(188,189.3-189.9)$ & 30 & 1.40 & 0.95 to 2.00 & 19 & 0.86 & 0.52 to 1.35 & 21 & 0.69 & 0.43 to 1.05 & 27 & 1.02 & 0.67 to 1.48 \\
\hline Brain and CNS (191-192) & 29 & 0.90 & 0.60 to 1.29 & 6 & $0.28^{\star}$ & 0.10 to 0.60 & 17 & 0.70 & 0.41 to 1.13 & 17 & 0.83 & 0.48 to 1.33 \\
\hline \multicolumn{13}{|l|}{ Non-Hodgkin's lymphoma } \\
\hline$(200,202)$ & 31 & 0.75 & 0.51 to 1.07 & 26 & 0.80 & 0.52 to 1.17 & 36 & 0.92 & 0.66 to 1.28 & 44 & 1.32 & 0.96 to 1.78 \\
\hline Hodgkin's disease (201) & 4 & 0.53 & 0.15 to 1.36 & 5 & 1.10 & 0.36 to 2.57 & 7 & 1.54 & 0.62 to 3.17 & 1 & 0.42 & 0.01 to 2.33 \\
\hline Multiple myeloma (203) & 20 & 1.06 & 0.65 to 1.63 & 23 & 1.31 & 0.83 to 1.96 & 22 & 0.99 & 0.62 to 1.50 & 25 & 1.40 & 0.90 to 2.07 \\
\hline \multicolumn{13}{|l|}{ Leukaemia and aleukaemia } \\
\hline$(204-208)$ & 47 & 1.21 & 0.89 to 1.61 & 23 & 0.76 & 0.48 to 1.14 & 38 & 1.02 & 0.72 to 1.40 & 38 & 1.15 & 0.82 to 1.59 \\
\hline Diabetes $(250)$ & 56 & 0.89 & 0.68 to 1.16 & 42 & 0.77 & 0.56 to 1.04 & 62 & 0.93 & 0.71 to 1.19 & 40 & $0.71^{\star}$ & 0.51 to 0.96 \\
\hline \multicolumn{13}{|l|}{ All heart disease $(390-398,402$, } \\
\hline $404,410-429)$ & 1230 & 0.94 & 0.89 to 0.99 & 1260 & 0.95 & 0.90 to 1.01 & 1597 & $0.90^{\star}$ & 0.85 to 0.94 & 1042 & $0.79^{\star}$ & 0.74 to 0.83 \\
\hline Cerebrovascular disease & & & & & & & & & & & & \\
\hline$(430-438)$ & 177 & 0.88 & 0.75 to 1.02 & 208 & $0.86^{\star}$ & 0.75 to 0.99 & 302 & 0.92 & 0.82 to 1.02 & 145 & $0.67^{\star}$ & 0.56 to 0.78 \\
\hline Non-malignant respiratory & & & & & & & & & & & & \\
\hline$(460-519)$ & 257 & 0.91 & 0.80 to 1.03 & 237 & $0.82^{\star}$ & 0.72 to 0.93 & 307 & $0.76^{\star}$ & 0.68 to 0.85 & 231 & $0.65^{\star}$ & 0.57 to 0.74 \\
\hline Emphysema (492) & 40 & 0.91 & 0.65 to 1.24 & 34 & $0.69^{\star}$ & 0.48 to 0.96 & 66 & 0.95 & 0.73 to 1.20 & 37 & 0.71 & 0.50 to 0.97 \\
\hline Asthma (493) & 6 & 0.72 & 0.27 to 1.57 & 5 & 0.73 & 0.24 to 1.70 & 6 & 0.79 & 0.29 to 1.72 & 5 & 0.90 & 0.29 to 2.09 \\
\hline Cirrhosis of liver (571) & 123 & $0.69^{\star}$ & 0.57 to 0.82 & 72 & $0.60^{\star}$ & 0.47 to 0.76 & 73 & $0.58^{\star}$ & 0.45 to 0.73 & 56 & $0.67^{\star}$ & 0.51 to 0.88 \\
\hline Nephritis and nephrosis & & & & & & & & & & & & \\
\hline$(580-589)$ & 16 & 0.69 & 0.39 to 1.12 & 25 & 1.12 & 0.73 to 1.65 & 35 & 1.23 & 0.86 to 1.71 & 18 & 0.82 & 0.49 to 1.30 \\
\hline All external causes (800-999) & 541 & $0.86^{\star}$ & 0.79 to 0.94 & 202 & $0.72^{\star}$ & 0.62 to 0.82 & 121 & $0.51^{\star}$ & 0.42 to 0.61 & 107 & $0.80^{\star}$ & 0.65 to 0.96 \\
\hline Accidents (850-949) & 313 & $0.87^{\star}$ & 0.78 to 0.97 & 114 & $0.69^{\star}$ & 0.57 to 0.83 & 79 & $0.54^{\star}$ & 0.43 to 0.68 & 66 & 0.83 & 0.64 to 1.06 \\
\hline Suicides $(950-959)$ & 126 & $0.82^{\star}$ & 0.69 to 0.98 & 62 & 0.83 & 0.63 to 1.06 & 30 & $0.43^{\star}$ & 0.29 to 0.62 & 39 & 0.89 & 0.64 to 1.22 \\
\hline Unknown cause of death & 113 & & & 40 & & & 49 & & & 16 & & \\
\hline
\end{tabular}

${ }^{\star} \mathrm{p}<0.05$

and cirrhosis of the liver (SMR 0.60; 95\% CI 0.48 to 0.73 ).

OCCUPATIONAL FAMILY GROUPS

Analyses of factory workers classified into eight broad occupational families showed significant deficits in all cancer mortality, with SMRs ranging between 0.79 and 0.94 (table 6). Workers in research and development had the lowest rates for most causes of death, including a significant deficit of lung cancer (SMR 0.70). The largest family of factory workers, assembly, also had a significantly low rate of dying from lung cancer. Fabrication workers, who were exposed to a wide range of chemical and other substances, including classified compounds within the Skunk Works, experienced no remarkable cancer patterns. Process equipment workers, who worked on the tank lines and received the heaviest exposure to TCE, PCE, and chromic acid, also experienced no significant increases in specific types of cancer. The rate for lung cancer among maintenance workers was significantly low (SMR 0.79), based on 134 deaths. The electrical and electronics family had the highest proportion of women workers; their mortality patterns were not remarkable. Workers in the machine shop were exposed to cutting oils and wipe solvents and had significantly low risks of prostate cancer (SMR 0.75).

\section{SPECIFIC OCCUPATIONS}

The SMRs among workers in occupations likely to experience exposures of interest are shown in table 7 . Painters, who worked with chromate based paints and primers and routinely used some type of solvent, were followed up for an average of 24 years. Their all cancer mortality (SMR 0.87) was lower than expected but not significantly. Their risk of lung cancer was not significantly higher than 
Table 6 Standardised mortality ratios of selected causes of death for Lockheed Martin factory workers employed in aircraft manufacturing for at least 1 year since 1960 and followed up to the end of 1996 by occupational family group (sex and race combined)

\begin{tabular}{|c|c|c|c|c|c|c|c|c|c|c|c|c|}
\hline \multirow[b]{2}{*}{ Cause of death (ICD-9) } & \multicolumn{3}{|c|}{$\begin{array}{l}\text { Assembly }(n=24295) \\
606410 \text { person-years }\end{array}$} & \multicolumn{3}{|c|}{$\begin{array}{l}\text { Fabrication }(n=11004) \\
273770 \text { person-years }\end{array}$} & \multicolumn{3}{|c|}{$\begin{array}{l}\text { Processing }(n=3225) \\
78132 \text { person-years }\end{array}$} & \multicolumn{3}{|c|}{$\begin{array}{l}\text { Maintenance }(n=4153) \\
98000 \text { person-years }\end{array}$} \\
\hline & Obs & $S M R$ & $95 \% C I$ & Obs & $S M R$ & $95 \% C I$ & Obs & $S M R$ & $95 \% C I$ & Obs & $S M R$ & $95 \% C I$ \\
\hline $\begin{array}{l}\text { All causes of death (001-999) } \\
\text { All malignant neoplasms }\end{array}$ & 7910 & $0.86^{\star}$ & 0.84 to 0.88 & 3913 & $0.86^{\star}$ & 0.83 to 0.88 & 1029 & $0.88^{\star}$ & 0.83 to 0.93 & 1926 & $0.85^{\star}$ & 0.81 to 0.88 \\
\hline$(140-208)$ & 2036 & $0.91^{\star}$ & 0.87 to 0.95 & 1027 & $0.92^{\star}$ & 0.87 to 0.98 & 247 & $0.87^{\star}$ & 0.77 to 0.99 & 463 & $0.87^{\star}$ & 0.79 to 0.95 \\
\hline Oesophagus (150) & 47 & 0.79 & 0.58 to 1.05 & 26 & 0.86 & 0.56 to 1.26 & 6 & 0.74 & 0.27 to 1.62 & 14 & 1.01 & 0.55 to 1.70 \\
\hline \multicolumn{13}{|l|}{ Biliary passages and liver } \\
\hline$(155,156)$ & 54 & 1.02 & 0.77 to 1.34 & 23 & 0.88 & 0.56 to 1.32 & 5 & 0.74 & 0.24 to 1.71 & 7 & 0.57 & 0.23 to 1.18 \\
\hline Pancreas $(157)$ & 106 & 0.90 & 0.74 to 1.09 & 53 & 0.91 & 0.68 to 1.18 & 14 & 0.95 & 0.52 to 1.59 & 21 & 0.74 & 0.46 to 1.13 \\
\hline \multicolumn{13}{|l|}{ Bronchus, trachea, and lung } \\
\hline$(162)$ & 659 & $0.92^{\star}$ & 0.85 to 0.99 & 330 & 0.92 & 0.82 to 1.03 & 89 & 0.99 & 0.80 to 1.22 & 134 & $0.79^{\star}$ & 0.66 to 0.94 \\
\hline Breast $(174,175)$ & 39 & 0.87 & 0.62 to 1.19 & 19 & 1.04 & 0.62 to 1.62 & 9 & 1.44 & 0.66 to 2.74 & 6 & 1.04 & 0.38 to 2.26 \\
\hline Ovary (women only) (183) & 13 & 0.94 & 0.50 to 1.61 & 7 & 1.24 & 0.50 to 2.56 & 1 & 0.52 & 0.01 to 2.91 & 5 & 2.97 & 0.96 to 6.93 \\
\hline Prostate (men only) $(185)$ & 210 & 1.06 & 0.92 to 1.22 & 119 & 1.15 & 0.95 to 1.37 & 19 & 0.76 & 0.46 to 1.18 & 67 & 1.18 & 0.91 to 1.50 \\
\hline Kidney (189.0-189.2) & 37 & 0.74 & 0.52 to 1.02 & 19 & 0.77 & 0.46 to 1.20 & 4 & 0.65 & 0.18 to 1.67 & 11 & 0.95 & 0.47 to 1.69 \\
\hline \multicolumn{13}{|l|}{ Non-Hodgkin's lymphoma } \\
\hline$(200,202)$ & 74 & 0.89 & 0.70 to 1.12 & 42 & 1.03 & 0.74 to 1.39 & 10 & 0.98 & 0.47 to 1.81 & 15 & 0.78 & 0.44 to 1.29 \\
\hline Multiple myeloma (203) & 53 & 1.19 & 0.89 to 1.56 & 26 & 1.17 & 0.76 to 1.71 & 6 & 1.05 & 0.39 to 2.29 & 14 & 1.27 & 0.70 to 2.13 \\
\hline \multicolumn{13}{|l|}{ Leukaemia and aleukaemia } \\
\hline$(204-208)$ & 83 & 1.04 & 0.83 to 1.29 & 42 & 1.06 & 0.77 to 1.44 & 9 & 0.91 & 0.42 to 1.74 & 18 & 0.94 & 0.56 to 1.49 \\
\hline
\end{tabular}

${ }^{\star} \mathrm{p}<0.05$.

†Expected value.

expected (SMR 1.11, observed 41). Processing operators and helpers and electroplaters, who routinely worked with vapour degreasers and metal processing tanks where exposure to TCE, PCE, and chromic acid was likely, also had no significant excess of total cancer or cancers of the lung, larynx, or non-Hodgkin's lymphoma.

Plastic parts fabricators, who were potentially exposed to a wide range of substances including asbestos and mixed solvents, experienced no significant increases in mortality. Welders would also be exposed to non-ionising electromagnetic fields, but no significant increases were found for either brain cancer or leukaemia. There were no significant increases among metal bonders, fabrication and structural design mechanics, or final assemblers.

ROUTINE EXPOSURE TO CHROMATE, TCE, PCE, MIXED SOLVENTS, AND OTHER SUBSTANCES Table 8 presents SMR analyses of workers who had the potential for routine exposure to chromate, TCE, PCE, and mixed solvents. Among workers routinely exposed to chromate from paints or processing lines, cancer of the buccal cavity and pharynx occurred significantly below expectation (SMR 0.14), lung cancer was as expected (SMR 1.02), and all cancer mortality was below expectation (SMR 0.93) but not significantly. The larger group of over 7400 workers with any chromate exposure (data not presented), either routinely or intermittently, also had no significantly increased causes of death, including cancer. Mortality from all cancer was below expectation (SMR $0.88 ; 95 \%$ CI 0.81 to 0.95 ) as was lung cancer (SMR 0.89; 95\% CI 0.78 to 1.03 ).

There were no significant increases of any cause of death among the workers potentially exposed to TCE on a routine basis. All cancer mortality was significantly low (SMR 0.86) as were the numbers of deaths due to cancers of the pancreas (SMR 0.41) and lung (SMR 0.76). Deaths due to non-Hodgkin's lymphoma (SMR 1.19) were slightly above expected levels but not significantly. Cancer of the liver (SMR 0.54) occurred below expectation but not significantly. The SMRs for the workers with any potential exposure to TCE, either routinely or intermittently (data not presented), were similar to those for workers

Table 7 Standardised mortality ratios of selected causes of death for Lockheed Martin factory workers employed in aircraft manufacturing for at least 1 year since 1960 and followed up to the end of 1996 by specific occupations (sex and race combined)

\begin{tabular}{|c|c|c|c|c|c|c|c|c|c|}
\hline \multirow[b]{2}{*}{ Cause of death (ICD-9) } & \multicolumn{3}{|c|}{$\begin{array}{l}\text { Painter }(n=1216) \\
29163 \text { person-years }\end{array}$} & \multicolumn{3}{|c|}{$\begin{array}{l}\text { Process operator or plater }(n=1626)+ \\
37277 \text { person-years }\end{array}$} & \multicolumn{3}{|c|}{$\begin{array}{l}\text { Plastics parts fabricator }(n=2681) \\
60033 \text { person-years }\end{array}$} \\
\hline & Obs & $S M R$ & $95 \% C I$ & Obs & $S M R$ & $95 \% C I$ & Obs & $S M R$ & $95 \% C I$ \\
\hline All causes of death (001-999) & 435 & $0.89^{\star}$ & 0.81 to 0.98 & 442 & 0.91 & 0.83 to 1.00 & 549 & $0.86^{\star}$ & 0.79 to 0.94 \\
\hline All malignant neoplasms (140-208) & 101 & 0.87 & 0.71 to 1.06 & 116 & 0.97 & 0.80 to 1.17 & 139 & 0.88 & 0.74 to 1.04 \\
\hline Oesophagus (150) & 2 & 0.61 & 0.07 to 2.20 & 3 & 0.88 & 0.18 to 2.58 & 2 & 0.43 & 0.05 to 1.54 \\
\hline Biliary passages and liver $(155,156)$ & 1 & 0.36 & 0.01 to 2.03 & 5 & 1.71 & 0.54 to 3.94 & 4 & 1.01 & 0.28 to 2.59 \\
\hline Pancreas (157) & 4 & 0.66 & 0.18 to 1.70 & 8 & 1.29 & 0.56 to 2.55 & 7 & 0.87 & 0.35 to 1.79 \\
\hline Bronchus, trachea, and lung (162) & 41 & 1.11 & 0.80 to 1.51 & 38 & 1.03 & 0.73 to 1.41 & 51 & 0.99 & 0.74 to 1.30 \\
\hline Breast $(174,175)$ & 1 & 0.67 & 0.02 to 3.71 & 4 & 0.94 & 0.25 to 2.42 & 4 & 1.24 & 0.34 to 3.17 \\
\hline Ovary (women only) (183) & 0 & {$[0.46] \ddagger$} & 0.00 to 8.05 & 1 & 0.76 & 0.02 to 4.25 & 1 & 1.14 & 0.03 to 6.34 \\
\hline Prostate (men only) (185) & 12 & 1.07 & 0.55 to 1.87 & 6 & 0.65 & 0.24 to 1.41 & 14 & 1.13 & 0.62 to 1.90 \\
\hline Kidney (189.0-189.2) & 2 & 0.79 & 0.10 to 2.86 & 2 & 0.79 & 0.09 to 2.86 & 7 & 1.92 & 0.77 to 3.96 \\
\hline Non-Hodgkin's lymphoma $(200,202)$ & 3 & 0.72 & 0.15 to 2.12 & 8 & 1.88 & 0.81 to 3.71 & 7 & 1.18 & 0.48 to 2.43 \\
\hline Multiple myeloma (203) & 4 & 1.70 & 0.46 to 4.35 & 0 & {$[2.37] \neq$} & 0.00 to 1.56 & 2 & 0.66 & 0.08 to 2.37 \\
\hline Leukaemia and aleukaemia (204-208) & 3 & 0.74 & 0.15 to 2.16 & 4 & 0.98 & 0.26 to 2.52 & 2 & 0.36 & 0.04 to 1.29 \\
\hline
\end{tabular}

${ }^{\star} \mathrm{p}<0.05$.

†Includes 1440 process equipment operators plus 186 electroplaters.

$\ddagger$ Expected value. 
Table 6 (Continued)

\begin{tabular}{|c|c|c|c|c|c|c|c|c|c|c|c|}
\hline \multicolumn{3}{|c|}{$\begin{array}{l}\text { Research and development }(n=5024) \\
127673 \text { person-years }\end{array}$} & \multicolumn{3}{|c|}{$\begin{array}{l}\text { Electrical }(n=9014) \\
229666 \text { person-years }\end{array}$} & \multicolumn{3}{|c|}{$\begin{array}{l}\text { Machine shop }(n=8027) \\
199572 \text { person-years }\end{array}$} & \multicolumn{3}{|c|}{$\begin{array}{l}\text { Tooling }(n=5960) \\
154615 \text { person-years }\end{array}$} \\
\hline Obs & $S M R$ & $95 \% C I$ & $O b s$ & $S M R$ & $95 \% C I$ & $O b s$ & $S M R$ & $95 \% C I$ & Obs & $S M R$ & $95 \% C I$ \\
\hline 2122 & $0.76^{\star}$ & 0.73 to 0.79 & 2955 & $0.83^{\star}$ & 0.80 to 0.86 & 2764 & $0.87^{\star}$ & 0.84 to 0.90 & 2423 & $0.84^{\star}$ & 0.81 to 0.87 \\
\hline 551 & $0.79^{\star}$ & 0.73 to 0.86 & 810 & $0.90^{\star}$ & 0.84 to 0.96 & 677 & $0.90^{\star}$ & 0.83 to 0.97 & 658 & 0.94 & 0.87 to 1.01 \\
\hline 14 & 0.75 & 0.41 to 1.25 & 21 & 0.99 & 0.62 to 1.52 & 24 & 1.23 & 0.79 to 1.83 & 15 & 0.81 & 0.45 to 1.34 \\
\hline 15 & 0.94 & 0.52 to 1.54 & 12 & 0.57 & 0.30 to 1.00 & 22 & 1.26 & 0.79 to 1.90 & 10 & 0.62 & 0.30 to 1.14 \\
\hline 26 & 0.71 & 0.46 to 1.04 & 40 & 0.84 & 0.60 to 1.15 & 39 & 0.98 & 0.70 to 1.34 & 34 & 0.92 & 0.64 to 1.29 \\
\hline 162 & $0.70^{\star}$ & 0.60 to 0.82 & 243 & 0.90 & 0.79 to 1.03 & 225 & 0.94 & 0.82 to 1.07 & 226 & 0.98 & 0.85 to 1.11 \\
\hline 2 & 0.77 & 0.09 to 2.78 & 56 & 1.16 & 0.87 to 1.50 & 9 & 0.89 & 0.41 to 1.69 & 4 & 1.03 & 0.28 to 2.64 \\
\hline 0 & {$[0.60] \dagger$} & 0.00 to 6.14 & 19 & 1.22 & 0.74 to 1.91 & 4 & 1.27 & 0.35 to 3.24 & 1 & 0.96 & 0.02 to 5.34 \\
\hline 80 & 1.10 & 0.87 to 1.37 & 72 & 1.11 & 0.87 to 1.39 & 53 & $0.75^{\star}$ & 0.56 to 0.98 & 66 & 0.93 & 0.72 to 1.19 \\
\hline 9 & 0.57 & 0.26 to 1.08 & 23 & 1.22 & 0.77 to 1.82 & 13 & 0.76 & 0.41 to 1.31 & 12 & 0.75 & 0.39 to 1.30 \\
\hline 29 & 1.15 & 0.77 to 1.65 & 38 & 1.14 & 0.81 to 1.57 & 26 & 0.91 & 0.60 to 1.34 & 23 & 0.88 & 0.56 to 1.32 \\
\hline 17 & 1.23 & 0.72 to 1.98 & 17 & 0.96 & 0.56 to 1.54 & 17 & 1.13 & 0.66 to 1.81 & 20 & 1.43 & 0.88 to 2.21 \\
\hline 15 & 0.61 & 0.34 to 1.01 & 33 & 1.07 & 0.73 to 1.50 & 25 & 0.91 & 0.59 to 1.34 & 24 & 0.95 & 0.61 to 1.41 \\
\hline
\end{tabular}

with daily potential exposure: all cancers (SMR 0.86; 95\% CI 0.79 to 0.92), lung (SMR $0.76 ; 95 \%$ CI 0.66 to 0.87 ) and liver (SMR $0.81 ; 95 \%$ CI 0.45 to 1.33 ), and nonHodgkin's lymphoma (SMR 1.19; 95\% CI 0.83 to 1.65 ).

Perchloroethylene replaced TCE around 1966 and overlapping exposure with TCE was noted for $30 \%$ of these workers. There were no significantly high or low SMRs for any cancer among workers routinely exposed to PCE. Deaths due to non-Hodgkin's lymphoma (SMR 1.70) and liver cancer (SMR 2.05) were above expected levels but not significantly. Cancer of the kidney (SMR 0.69) occurred below expectation but not significantly. The SMRs for cancer among the workers with potential for any exposure to PCE (data not presented) were similar but somewhat lower than among those routinely exposed to PCE - for example, for all cancer (SMR 0.87; $95 \%$ CI 0.78 to 0.95 ), cancers of the liver (SMR 0.95; 95\% CI 0.47 to 1.70 ), lung (SMR 0.85 ; $95 \%$ CI 0.71 to 1.00 ), and nonHodgkin's lymphoma (SMR $1.41 ; 95 \%$ CI 0.90 to 2.10 ).
Among factory workers exposed to mixed solvents on a routine basis, no significant increases of any cause of death were found except for testicular or other male genital cancers (SMR 3.04) based on six deaths, including five testis and one penile cancer. The excess could not be linked to any particular solvent. Non-significant deficits were found for all cancer (SMR 0.89) and for lung cancer (SMR 0.88, observed 221). Cancers of the liver (SMR 0.92), kidney (SMR 0.81), multiple myeloma (SMR 0.98), and non-Hodgkin's lymphoma (SMR 1.02) were not significantly diVerent from expectation. No excesses of non-malignant diseases were found, including nephritis (SMR 0.70, observed 14). Among workers routinely or intermittently exposed to mixed solvents (data not presented), no significantly high SMRs were observed and significant deficits were found for all cancer (SMR 0.92; 95\% CI 0.88 to 0.95) and several specific cancers. The SMRs for the ever exposed group were similar to those for the routinely exposed for all cancers (SMR 0.92), cancers of the liver (SMR 0.91; 95\% CI 0.70 to 1.17 ), brain (SMR $0.70 ; 95 \%$ CI 0.52 to

Table 7 (Continued)

\begin{tabular}{|c|c|c|c|c|c|c|c|c|c|c|c|}
\hline \multicolumn{3}{|c|}{$\begin{array}{l}\text { Welder }(n=810) \\
21611 \text { person-years }\end{array}$} & \multicolumn{3}{|c|}{$\begin{array}{l}\text { Metal bonder }(n=1162) \\
24218 \text { person-years }\end{array}$} & \multicolumn{3}{|c|}{$\begin{array}{l}\text { Fabrication and structures development } \\
\text { mechanic }(n=2425) 61648 \text { person-years }\end{array}$} & \multicolumn{3}{|c|}{$\begin{array}{l}\text { Final assembler }(n=20898) \\
521152 \text { person-years }\end{array}$} \\
\hline Obs & $S M R$ & $95 \% C I$ & Obs & $S M R$ & $95 \% C I$ & Obs & $S M R$ & $95 \% C I$ & Obs & $S M R$ & $95 \% C I$ \\
\hline 375 & $0.82^{\star}$ & 0.74 to 0.91 & 270 & 1.00 & 0.89 to 1.13 & 1101 & $0.76^{\star}$ & 0.72 to 0.81 & 6688 & $0.86^{\star}$ & 0.84 to 0.88 \\
\hline 117 & 1.05 & 0.86 to 1.25 & 68 & 1.07 & 0.83 to 1.35 & 296 & $0.81^{\star}$ & 0.72 to 0.91 & 1732 & $0.92^{\star}$ & 0.87 to 0.96 \\
\hline 2 & 0.69 & 0.08 to 2.48 & 4 & 2.07 & 0.56 to 5.30 & 9 & 0.89 & 0.41 to 1.68 & 39 & 0.77 & 0.54 to 1.05 \\
\hline 3 & 1.17 & 0.24 to 3.43 & 2 & 1.24 & 0.15 to 4.46 & 7 & 0.83 & 0.33 to 1.71 & 48 & 1.07 & 0.79 to 1.42 \\
\hline 5 & 0.85 & 0.28 to 1.98 & 2 & 0.61 & 0.07 to 2.21 & 18 & 0.94 & 0.56 to 1.48 & 94 & 0.95 & 0.77 to 1.16 \\
\hline 37 & 1.01 & 0.71 to 1.39 & 24 & 1.16 & 0.74 to 1.72 & 77 & $0.63^{\star}$ & 0.50 to 0.78 & 559 & 0.93 & 0.85 to 1.01 \\
\hline 1 & 1.21 & 0.03 to 6.76 & 1 & 1.20 & 0.03 to 6.70 & 1 & 1.21 & 0.03 to 6.71 & 31 & 0.80 & 0.55 to 1.14 \\
\hline 0 & {$[0.24] \ddagger$} & 0.00 to 15.6 & 0 & {$[0.21] \ddagger$} & 0.00 to 17.9 & 0 & {$[0.13] \ddagger$} & 0.00 to 29.3 & 9 & 0.76 & 0.35 to 1.44 \\
\hline 16 & 1.39 & 0.79 to 2.25 & 4 & 0.74 & 0.20 to 1.91 & 42 & 1.08 & 0.78 to 1.46 & 184 & 1.11 & 0.95 to 1.28 \\
\hline 2 & 0.79 & 0.10 to 2.86 & 3 & 2.04 & 0.42 to 5.95 & 2 & $0.24^{\star}$ & 0.03 to 0.88 & 31 & 0.74 & 0.50 to 1.05 \\
\hline 1 & 0.24 & 0.01 to 1.35 & 2 & 0.84 & 0.10 to 3.03 & 17 & 1.31 & 0.76 to 2.09 & 66 & 0.94 & 0.73 to 1.20 \\
\hline 4 & 1.78 & 0.49 to 4.58 & 1 & 0.79 & 0.02 to 4.42 & 8 & 1.11 & 0.48 to 2.18 & 41 & 1.09 & 0.79 to 1.48 \\
\hline 5 & 1.25 & 0.41 to 2.92 & 2 & 0.87 & 0.11 to 3.15 & 6 & 0.47 & 0.17 to 1.03 & 68 & 1.01 & 0.79 to 1.29 \\
\hline
\end{tabular}


Table 8 Standardised mortality ratios for Lockheed Martin factory workers employed in aircraft manufacturing for at least 1 year since 1960 and followed up to the end of 1996 with potential routine exposure to selected agents (sex and race combined)

\begin{tabular}{|c|c|c|c|c|c|c|c|c|c|c|c|c|}
\hline \multirow[b]{2}{*}{ Cause of death (ICD-9) } & \multicolumn{3}{|c|}{$\begin{array}{l}\text { Chromate }(n=3634) \\
88224 \text { person-years }\end{array}$} & \multicolumn{3}{|c|}{$\begin{array}{l}\text { Trichloroethylene }(n=2267) \\
66183 \text { person-years }\end{array}$} & \multicolumn{3}{|c|}{$\begin{array}{l}\text { Perchloroethylene }(n=2631) \\
51214 \text { person-years }\end{array}$} & \multicolumn{3}{|c|}{$\begin{array}{l}\text { Mixed solvents }(n=9201) \\
218384 \text { person-years }\end{array}$} \\
\hline & Obs & $S M R$ & $95 \% C I$ & Obs & $S M R$ & $95 \% C I$ & Obs & $S M R$ & $95 \% C I$ & Obs & $S M R$ & $95 \% C I$ \\
\hline $\begin{array}{l}\text { All causes of death (001-999) } \\
\text { All malignant neoplasms }\end{array}$ & 1037 & $0.93^{\star}$ & 0.87 to 0.98 & 1110 & $0.83^{\star}$ & 0.79 to 0.88 & 476 & $0.90^{\star}$ & 0.82 to 0.98 & 2681 & $0.84^{\star}$ & 0.81 to 0.88 \\
\hline \multicolumn{13}{|l|}{ All malignant neoplasms } \\
\hline \multicolumn{13}{|l|}{ Buccal cavity and pharynx } \\
\hline$(140-149)$ & 1 & $0.14^{\star}$ & 0.00 to 0.77 & 5 & 0.60 & 0.20 to 1.40 & 2 & 0.55 & 0.07 to 1.99 & 9 & $0.43^{\star}$ & 0.20 to 0.82 \\
\hline Oesophagus (150) & 8 & 1.04 & 0.45 to 2.05 & 7 & 0.83 & 0.34 to 1.72 & 6 & 1.47 & 0.54 to 3.21 & 18 & 0.83 & 0.49 to 1.31 \\
\hline Stomach (151) & 11 & 1.03 & 0.51 to 1.84 & 17 & 1.32 & 0.77 to 2.12 & 7 & 1.42 & 0.57 to 2.93 & 23 & 0.76 & 0.48 to 1.13 \\
\hline Colon (153) & 23 & 1.02 & 0.65 to 1.53 & 30 & 1.07 & 0.72 to 1.52 & 7 & 0.66 & 0.27 to 1.36 & 68 & 1.05 & 0.81 to 1.33 \\
\hline Rectum (154) & 6 & 1.08 & 0.40 to 2.36 & 9 & 1.29 & 0.59 to 2.45 & 3 & 1.23 & 0.25 to 3.58 & 18 & 1.13 & 0.67 to 1.78 \\
\hline \multicolumn{13}{|l|}{ Biliary passages and liver } \\
\hline$(155,156)$ & 7 & 1.07 & 0.43 to 2.20 & 4 & 0.54 & 0.15 to 1.38 & 7 & 2.05 & 0.83 to 4.23 & 17 & 0.92 & 0.54 to 1.47 \\
\hline Pancreas (157) & 14 & 1.00 & 0.55 to 1.68 & 7 & $0.41^{\star}$ & 0.17 to 0.85 & 10 & 1.50 & 0.72 to 2.76 & 31 & 0.77 & 0.52 to 1.09 \\
\hline Larynx (161) & 3 & 0.96 & 0.20 to 2.80 & 4 & 1.10 & 0.30 to 2.82 & 1 & 0.64 & 0.02 to 3.55 & 5 & 0.55 & 0.18 to 1.29 \\
\hline \multicolumn{13}{|l|}{ Bronchus, trachea, and lung } \\
\hline$(162)$ & 87 & 1.02 & 0.82 to 1.26 & 78 & $0.76^{\star}$ & 0.60 to 0.95 & 46 & 1.08 & 0.79 to 1.44 & 221 & 0.88 & 0.77 to 1.01 \\
\hline Bone (170) & 0 & {$[0.63] \dagger$} & 0.00 to 5.90 & 1 & 1.44 & 0.04 to 8.02 & 0 & {$[0.31] \dagger$} & 0.00 to 12.1 & 1 & 0.57 & 0.01 to 3.18 \\
\hline Connective tissue (171) & 3 & 2.06 & 0.42 to 6.00 & 3 & 1.94 & 0.40 to 5.67 & 2 & 2.46 & 0.30 to 8.90 & 5 & 1.21 & 0.39 to 2.82 \\
\hline Melanoma of skin (172) & 2 & 0.51 & 0.06 to 1.85 & 2 & 0.46 & 0.06 to 1.67 & 2 & 0.95 & 0.12 to 3.43 & 10 & 0.87 & 0.42 to 1.60 \\
\hline Breast $(174,175)$ & 6 & 0.99 & 0.36 to 2.15 & 7 & 1.31 & 0.53 to 2.69 & 4 & 1.16 & 0.32 to 2.97 & 15 & 1.26 & 0.70 to 2.07 \\
\hline \multicolumn{13}{|l|}{ All uterine (women only) } \\
\hline$(179-182)$ & 0 & {$[1.77] \dagger$} & 0.00 to 2.09 & 1 & 0.64 & 0.02 to 3.57 & 0 & {$[0.93] \dagger$} & 0.00 to 3.95 & 1 & 0.31 & 0.01 to 1.71 \\
\hline \multicolumn{13}{|l|}{ Cervix uteri (women only) } \\
\hline$(180)$ & 0 & {$[0.83] \dagger$} & 0.00 to 4.42 & 0 & {$[0.67] \dagger$} & 0.00 to 5.54 & 0 & {$[0.47] \dagger$} & 0.00 to 7.77 & 0 & {$[1.55] \dagger$} & 0.00 to 2.37 \\
\hline Ovary (women only) (183) & 1 & 0.55 & 0.01 to 3.04 & 1 & 0.58 & 0.01 to 3.22 & 0 & {$[0.97] \dagger$} & 0.00 to 3.79 & 2 & 0.57 & 0.07 to 2.07 \\
\hline Prostate (men only) (185) & 20 & 0.46 & 0.53 to 1.33 & 32 & 1.03 & 0.70 to 1.45 & 12 & 1.14 & 0.59 to 1.99 & 70 & 1.00 & 0.78 to 1.26 \\
\hline \multicolumn{13}{|l|}{ Testis and other male genital } \\
\hline$(186,187)$ & 3 & 4.21 & 0.87 to 12.3 & 0 & {$[0.68] \dagger$} & 0.00 to 5.42 & 1 & 2.64 & 0.07 to 14.7 & 6 & $3.04^{\star}$ & 1.12 to 6.63 \\
\hline Kidney (189.0-189.2) & 7 & 1.19 & 0.48 to 2.45 & 7 & 0.99 & 0.40 to 2.04 & 2 & 0.69 & 0.08 to 2.47 & 14 & 0.81 & 0.44 to 1.36 \\
\hline \multicolumn{13}{|l|}{ Bladder and other urinary } \\
\hline$(188,189.3-189.9)$ & 3 & 0.45 & 0.09 to 1.30 & 5 & 0.55 & 0.18 to 1.28 & 2 & 0.70 & 0.09 to 2.53 & 17 & 0.85 & 0.49 to 1.35 \\
\hline Brain and CNS (191-192) & 3 & 0.46 & 0.09 to 1.34 & 4 & 0.54 & 1.37 & 2 & 0.59 & 0.07 to 2.14 & 13 & 0.68 & 0.36 to 1.16 \\
\hline \multicolumn{13}{|l|}{ Non-Hodgkin's lymphoma } \\
\hline$(200,202)$ & 10 & 1.02 & 0.49 to 1.88 & 14 & 1.19 & 0.65 to 1.99 & 8 & 1.70 & 0.73 to 3.34 & 29 & 1.02 & 0.68 to 1.47 \\
\hline Hodgkin's disease (201) & 4 & 3.01 & 0.82 to 7.70 & 4 & 2.77 & 0.76 to 7.10 & 0 & {$[0.63] \ddagger$} & 0.00 to 5.81 & 6 & 1.61 & 0.59 to 3.51 \\
\hline Multiple myeloma (203) & 5 & 0.93 & 0.30 to 2.17 & 6 & 0.91 & 0.34 to 1.99 & 1 & 0.40 & 0.01 to 2.25 & 15 & 0.98 & 0.55 to 1.61 \\
\hline \multicolumn{13}{|l|}{ Leukaemia and aleukaemia } \\
\hline$(204-208)$ & 8 & 0.85 & 0.37 to 1.67 & 12 & 1.05 & 0.54 to 1.84 & 5 & 1.09 & 0.35 to 2.55 & 28 & 1.02 & 0.68 to 1.48 \\
\hline Diabetes $(250)$ & 21 & 1.19 & 0.74 to 1.82 & 21 & 1.08 & 0.67 to 1.65 & 5 & 0.5 & 0.18 to 1.29 & 44 & 0.91 & 0.66 to 1.23 \\
\hline \multicolumn{13}{|l|}{ All heart disease $(390-398,402$, } \\
\hline $404,410-429)$ & 380 & 0.96 & 0.87 to 1.06 & 434 & $0.85^{\star}$ & 0.78 to 0.94 & 143 & $0.84^{\star}$ & 0.71 to 0.99 & 1027 & $0.90^{\star}$ & 0.85 to 0.96 \\
\hline Cerebrovascular disease & & & & & & & & & & & & \\
\hline$(430-438)$ & 52 & $0.73^{\star}$ & 0.55 to 0.96 & 59 & $0.66^{\star}$ & 0.50 to 0.85 & 25 & 0.86 & 0.56 to 1.27 & 150 & $0.77^{\star}$ & 0.65 to 0.90 \\
\hline Non-malignant respiratory & & & & & & & & & & & & \\
\hline$(460-51 \mathrm{C}$ & 88 & 0.98 & 0.79 to 1.21 & 104 & 0.88 & 0.72 to 1.06 & 32 & 0.80 & 0.55 to 1.13 & 213 & $0.81^{\star}$ & 0.71 to 0.93 \\
\hline Emphysema (492) & 17 & 1.20 & 0.70 to 1.91 & 16 & 0.80 & 0.46 to 1.30 & 3 & 0.54 & 0.11 to 1.58 & 34 & 0.80 & 0.55 to 1.12 \\
\hline Asthma (493) & 3 & 1.43 & 0.30 to 4.19 & 1 & 0.46 & 0.01 to 2.56 & 1 & 0.91 & 0.02 to 5.05 & 8 & 1.42 & 0.62 to 2.81 \\
\hline Cirrhosis of liver (571) & 34 & 0.98 & 0.68 to 1.37 & 23 & $0.61^{\star}$ & 0.39 to 0.91 & 15 & 0.84 & 0.47 to 1.38 & 77 & $0.77^{\star}$ & 0.60 to 0.96 \\
\hline Nephritis and nephrosis & & & & & & & & & & & & \\
\hline$(580-589)$ & 4 & 0.55 & 0.15 to 1.40 & 7 & 0.84 & 0.34 to 1.73 & 0 & {$[3.51] \dagger$} & 0.00 to 1.05 & 14 & 0.70 & 0.38 to 1.18 \\
\hline All external causes (800-999) & 78 & 0.81 & 0.64 to 1.00 & 47 & $0.57^{\star}$ & 0.42 to 0.76 & 46 & 0.80 & 0.58 to 1.06 & 184 & $0.71^{\star}$ & 0.61 to 0.82 \\
\hline Accidents (850-949) & 41 & $0.73^{\star}$ & 0.53 to 0.99 & 32 & $0.65^{\star}$ & 0.44 to 0.91 & 25 & 0.78 & 0.50 to 1.15 & 106 & $0.70^{\star}$ & 0.58 to 0.85 \\
\hline Suicides (950-959) & 16 & 0.68 & 0.39 to 1.11 & 10 & $0.44^{\star}$ & 0.21 to 0.80 & 9 & 0.69 & 0.32 to 1.31 & 44 & $0.67^{\star}$ & 0.48 to 0.89 \\
\hline Unknown cause of death & 20 & & & 18 & & & 9 & & & 38 & & \\
\hline
\end{tabular}

${ }^{\star} \mathrm{p}<0.05$.

†Expected value.

0.93), non-Hodgkin's lymphoma (SMR 0.94; $95 \%$ CI 0.77 to 1.14 ), leukaemia (SMR 1.07; $95 \%$ CI 0.88 to 1.29 ), and most other cancers. For testicular or other male genital cancer there was a non-significant increase (SMR $1.87 ; 95 \%$ CI 0.96 to 3.26 ) for workers with any exposure to mixed solvents.

Analyses were also conducted of workers routinely exposed to TCE but not PCE, to PCE but not TCE, to both TCE and PCE, and to any mixed solvent excluding TCE and PCE. The few observations resulted in increased instability of the SMRs, but the patterns of risk mirrored those presented in table 8 .

Mortality among workers exposed to asbestos and cutting oils was not remarkable (data not presented). Lung cancer was nonsignificantly increased among the 1231 workers potentially exposed to asbestos (SMR 1.38;
$95 \% 0.85$ to 1.94 ), with one death attributed to pleural mesothelioma. No unusual mortality patterns were found among the workers exposed to cutting oils.

INTERNAL COHORT COMPARISONS

Internal regression analyses by duration of exposure were conducted of workers routinely or intermittently exposed to chromate, TCE, PCE, and mixed solvents. Analyses of routine exposures alone had too few deaths to be meaningful. The workers with incomplete occupational histories were excluded so that numbers are not identical to those in the previous tables. For the factory workers exposed to chromate, there were no significantly positive or negative trends in risk for any cancer over years of potential exposure. For lung cancer, the relative risks over years of potential exposure to chromate $(0,<1,1-4, \geqslant 5$ years $)$ 
Table 9 Relative risk of selected cancers (ICD-9) by duration of potential exposure (routine or intermittent) to specific solvents for Lockheed Martin factory workers employed in aircraft manufacturing for at least 1 year since $1960+$

\begin{tabular}{|c|c|c|c|c|c|c|c|c|c|}
\hline \multirow{2}{*}{$\begin{array}{l}\text { Cancer (ICD-9) } \\
\text { years exposed }\end{array}$} & \multicolumn{3}{|c|}{ Trichloroethylene } & \multicolumn{3}{|c|}{ Perchloroethylene } & \multicolumn{3}{|c|}{ Mixed solvents } \\
\hline & $O b s$ & $R R$ & $95 \% C I$ & Obs & $R R$ & $95 \% C I$ & Obs & $R R$ & $95 \% C I$ \\
\hline \multicolumn{10}{|c|}{ Oesophagus (150): } \\
\hline 0 & 28 & 1.00 & & 28 & 1.00 & & 28 & 1.00 & \\
\hline$<1$ & 2 & $0.23^{\star}$ & 0.05 to 0.99 & 3 & 1.00 & 0.30 to 3.34 & 6 & 0.62 & 0.26 to 1.52 \\
\hline $1-4$ & 4 & 0.57 & 0.20 to 1.67 & 4 & 0.79 & 0.27 to 2.50 & 16 & 0.66 & 0.35 to 1.23 \\
\hline$\geqslant 5$ & 7 & 0.91 & $\begin{array}{l}0.38 \text { to } 2.22 \\
\mathrm{p}>0.20 \ddagger\end{array}$ & 3 & 0.91 & $\begin{array}{l}0.13 \text { to } 1.60 \\
p=0.07\end{array}$ & 34 & 0.70 & $\begin{array}{l}0.41 \text { to } 1.19 \\
p>0.20\end{array}$ \\
\hline \multicolumn{10}{|l|}{ Lung (162): } \\
\hline 0 & 288 & 1.00 & & 288 & 1.00 & & 288 & 1.00 & \\
\hline$<1$ & 66 & 0.85 & 0.65 to 1.13 & 33 & 1.15 & 0.80 to 1.66 & 85 & 0.92 & 0.72 to 1.18 \\
\hline $1-4$ & 63 & 0.98 & 0.74 to 1.30 & 51 & 1.09 & 0.80 to 1.48 & 238 & 0.96 & 0.81 to 1.14 \\
\hline$\geqslant 5$ & 44 & $0.64^{\star}$ & $\begin{array}{l}0.46 \text { to } 0.89 \\
\mathrm{p}<0.01\end{array}$ & 36 & 0.71 & $\begin{array}{l}0.49 \text { to } 1.02 \\
\mathrm{p}=0.02\end{array}$ & 410 & 0.99 & $\begin{array}{l}0.84 \text { to } 1.16 \\
p>0.20\end{array}$ \\
\hline \multicolumn{10}{|l|}{ Liver $(155,156)$ : } \\
\hline 0 & 22 & 1.00 & & 22 & 1.00 & & 22 & 1.00 & \\
\hline$<1$ & 4 & 0.53 & 0.18 to 1.60 & 3 & 1.38 & 0.40 to 4.69 & 10 & 1.35 & 0.63 to 2.87 \\
\hline $1-4$ & 3 & 0.52 & 0.15 to 1.79 & 4 & 1.17 & 0.39 to 3.47 & 14 & 0.75 & 0.38 to 1.47 \\
\hline$\geqslant 5$ & 6 & 0.94 & $\begin{array}{l}0.36 \text { to } 2.46 \\
p>0.20\end{array}$ & 5 & 1.29 & $\begin{array}{l}0.46 \text { to } 3.65 \\
p>0.20\end{array}$ & 31 & 0.97 & $\begin{array}{l}0.54 \text { to } 1.72 \\
\mathrm{p}>0.20\end{array}$ \\
\hline \multicolumn{10}{|c|}{ Kidney (189.0-189.2): } \\
\hline 0 & 22 & 1.00 & & 22 & 1.00 & & 22 & 1.00 & \\
\hline$<1$ & 6 & 0.97 & 0.37 to 2.50 & 1 & 0.49 & 0.07 to 3.68 & 11 & 1.54 & 0.74 to 3.20 \\
\hline $1-4$ & 1 & 0.19 & 0.02 to 1.42 & 2 & 0.56 & 0.13 to 2.41 & 19 & 1.08 & 0.58 to 2.01 \\
\hline$\geqslant 5$ & 4 & 0.69 & $\begin{array}{l}0.22 \text { to } 2.12 \\
p>0.20\end{array}$ & 2 & 0.46 & $\begin{array}{l}0.10 \text { to } 2.08 \\
\mathrm{p}=0.17\end{array}$ & 14 & $0.41^{\star}$ & $\begin{array}{l}0.20 \text { to } 0.82 \\
\mathrm{p}<0.01\end{array}$ \\
\hline \multicolumn{10}{|l|}{ Prostate (185): } \\
\hline 0 & 84 & 1.00 & & 84 & 1.00 & & 84 & 1.00 & \\
\hline$<1$ & 20 & 0.71 & 0.43 to 1.71 & 5 & 0.54 & 0.22 to 1.32 & 31 & 0.99 & 0.65 to 1.49 \\
\hline $1-4$ & 31 & 1.23 & 0.80 to 1.88 & 13 & 0.75 & 0.42 to 1.35 & 64 & 0.81 & 0.59 to 1.13 \\
\hline$\geqslant 5$ & 26 & 0.81 & $\begin{array}{l}0.51 \text { to } 1.28 \\
p>0.20\end{array}$ & 13 & 0.55 & $\begin{array}{l}0.30 \text { to } 1.01 \\
p=0.02\end{array}$ & 139 & 0.77 & $\begin{array}{l}0.58 \text { to } 1.02 \\
\mathrm{p}=0.06\end{array}$ \\
\hline \multicolumn{10}{|c|}{$\begin{array}{l}\text { Non-Hodgkin's lymphoma }(200,202) \text { : } \\
0\end{array}$} \\
\hline$<1$ & 32 & 1.00 & & 32 & 1.00 & & 32 & 1.00 & \\
\hline $1-4$ & 7 & 0.74 & 0.32 to 1.72 & 4 & 1.25 & 0.43 to 3.57 & 9 & 0.77 & 0.37 to 1.62 \\
\hline$\geqslant 5$ & 10 & 1.33 & 0.64 to 2.78 & 6 & 1.11 & 0.46 to 2.70 & 20 & 0.79 & 0.45 to 1.39 \\
\hline & 14 & 1.62 & $\begin{array}{l}0.82 \text { to } 3.22 \\
p=0.20\end{array}$ & 10 & 1.41 & $\begin{array}{l}0.67 \text { to } 3.00 \\
p>0.20\end{array}$ & 52 & 1.01 & $\begin{array}{l}0.64 \text { to } 1.61 \\
p>0.20\end{array}$ \\
\hline \multicolumn{10}{|c|}{ Multiple myeloma (203): } \\
\hline 0 & 24 & 1.00 & & 24 & 1.00 & & 24 & 1.00 & \\
\hline$<1$ & 3 & 0.45 & 0.13 to 1.54 & 1 & 0.46 & 0.06 to 3.48 & 3 & 0.34 & 0.10 to 1.14 \\
\hline $1-4$ & 8 & 1.48 & 0.64 to 3.41 & 4 & 1.13 & 0.38 to 3.35 & 13 & 0.63 & 0.32 to 1.25 \\
\hline$\geqslant 5$ & 3 & 0.51 & $\begin{array}{l}0.15 \text { to } 1.76 \\
p>0.20\end{array}$ & 1 & 0.24 & $\begin{array}{l}0.03 \text { to } 1.84 \\
\mathrm{p}<0.01\end{array}$ & 34 & 0.80 & $\begin{array}{l}0.46 \text { to } 1.38 \\
p>0.20\end{array}$ \\
\hline \multicolumn{10}{|c|}{ Total cancers (140-208): } \\
\hline 0 & 916 & 1.00 & & 916 & 1.00 & & 916 & 1.00 & \\
\hline$<1$ & 204 & $0.82^{\star}$ & 0.70 to 0.96 & 86 & 0.97 & 0.78 to 1.22 & 275 & 0.91 & 0.79 to 1.04 \\
\hline $1-4$ & 205 & 1.01 & 0.86 to 1.18 & 150 & 1.02 & 0.86 to 1.22 & 701 & 0.94 & 0.85 to 1.04 \\
\hline$\geqslant 5$ & 202 & 0.90 & $\begin{array}{l}0.76 \text { to } 1.06 \\
p>0.20\end{array}$ & 123 & $0.74^{\star}$ & $\begin{array}{l}0.61 \text { to } 0.90 \\
\mathrm{p}<0.01\end{array}$ & 1,254 & $0.91^{\star}$ & $\begin{array}{l}0.83 \text { to } 0.99 \\
\mathrm{p}=0.08\end{array}$ \\
\hline
\end{tabular}

${ }^{\star} \mathrm{p}<0.05$.

†Relative risks computed by Poisson regression with adjustment for date of birth, date first employed, date of finishing employment, race and sex. $\neq \mathrm{p}$ Value for trend (2 sided).

§The referent non-exposed group ( 0 y) was taken as factory workers not exposed to any solvent.

were $1.0,0.90$ (95\% CI 0.69 to 1.16$), 1.02$ ( $95 \%$ CI 0.78 to 1.33 ), and 1.08 (95\% CI 0.75 to 1.57 ), respectively ( $\mathrm{p}$ value for trend $>0.20$ ). For all cancers, the corresponding relative risks were $1.0,0.89$ (95\% CI 0.77 to 1.02$), 0.91$ (95\% CI 0.78 to 1.06$)$, and 1.00 (95\% CI 0.81 to 1.24$)$.

Table 9 presents internal cohort analyses of workers exposed to TCE, PCE, and mixed solvents on a routine or intermittent basis. There was a total of 611 cancers among the workers with potential for routine or intermittent exposure to TCE, but no variation in risk over categories of years worked was found overall or for specific cancers of initial interest. Among those with the longest durations of exposure, there was a non-significant increase for nonHodgkin's lymphoma (relative risk (RR) 1.62) and a significant deficit of lung cancer ( RR $0.64)$.

Among workers potentially exposed to PCE, there was no evidence of a significant increase in risk with increasing years of exposure for any cancer. As shown in table 9, among those with $\geqslant 5$ years of potential exposure, there were non-significant increases in liver cancer ( $R R$ 1.29) and non-Hodgkin's lymphoma (RR 1.41 ), but no indication of any significant linear exposure-response relations $(p>0.20)$. There was a significant decrease in total cancer ( RR 0.74 ) among those with the longest duration of exposure, and the lung cancer risk (RR 0.71) was also low.

Among the workers exposed to mixed solvents on a routine or intermittent basis during their occupation, there were no significant increases or increasing trends. The RRs among those exposed for $\geqslant 5$ years were close to or below 1.0 for total cancers (RR 0.91), liver cancer (RR 0.97), kidney cancer (RR 0.41 ), and non-Hodgkin's lymphoma (RR 1.01).

Other cancer sites evaluated included the testis, breast, and ovary but the numbers were 
Table 10 Standardised mortality comparisons among four studies of workers employed in aircraft manufacturing or repairt

\begin{tabular}{|c|c|c|c|c|c|c|c|c|}
\hline \multirow[b]{2}{*}{ Cause of death (ICD-9) } & \multicolumn{2}{|c|}{$\begin{array}{l}\text { Lockheed Martin } \\
\text { Current study } \\
n=77965 \text { 1960-96 } \\
1889795 \text { (24.2)S }\end{array}$} & \multicolumn{2}{|c|}{$\begin{array}{l}\text { Hill Air Force } \\
\text { Blair et al } 1998^{3} \\
n=144571952-90 \neq \\
\text { Not given }\end{array}$} & \multicolumn{2}{|c|}{$\begin{array}{l}\text { Hughes Aircraft } \\
\text { Morgan et al 1998 } \\
n=20508 \text { 1950-93 } \\
461617 \text { (22.5)S }\end{array}$} & \multicolumn{2}{|c|}{$\begin{array}{l}\text { San Diego } \\
\text { Garabrant et al } 1988 \\
n=140671958-82 \ddagger \\
222250(15.8) S\end{array}$} \\
\hline & Obs & $S M R$ & Obs & $S M R$ & Obs & $S M R$ & Obs & $S M R$ \\
\hline All causes of death (001-999) & 20236 & $0.83^{\star}$ & 5727 & $0.97^{\star}$ & 4052 & $0.85^{\star}$ & 1804 & $0.75^{\star}$ \\
\hline All malignant neoplasms $(140-208)$ & 5468 & $0.90^{\star}$ & 1048 & 0.96 & 1100 & $0.87^{\star}$ & 453 & $0.84^{\star}$ \\
\hline Buccal cavity and pharynx (140-149) & 101 & $0.65^{\star}$ & 19 & 0.98 & - & - & 10 & 0.61 \\
\hline Oesophagus (150) & 146 & 0.95 & 15 & 0.84 & - & - & 14 & 1.14 \\
\hline Stomach $(151)$ & 162 & $0.72^{\star}$ & 53 & 0.99 & - & - & 9 & $0.40^{\star}$ \\
\hline Colon (153) & 504 & 0.99 & 99 & 0.97 & - & - & 47 & 0.96 \\
\hline Rectum (154) & 102 & 0.82 & 17 & 0.78 & 18 & 0.71 & 15 & 1.04 \\
\hline Biliary passages and liver $(155,156)$ & 127 & 0.89 & 27 & 1.10 & 20 & 0.77 & 8 & 0.94 \\
\hline Pancreas (157) & 284 & 0.90 & 59 & 0.94 & 47 & 0.76 & 34 & 1.19 \\
\hline Larynx (161) & 51 & 0.79 & 6 & 0.69 & - & - & 0 & $0.00^{\star}$ \\
\hline Bronchus, trachea, and lung (162) & 1683 & $0.88^{\star}$ & 213 & 0.98 & 388 & 0.96 & 138 & $0.80^{\star}$ \\
\hline Bone $(170)$ & 10 & 0.74 & 7 & $2.27^{\star}$ & - & - & - & - \\
\hline Melanoma of skin (172) & 85 & 0.86 & 20 & 1.11 & - & - & 7 & 0.71 \\
\hline Breast $(174,175)$ & 202 & 1.05 & 49 & 0.82 & 47 & 0.75 & 16 & 0.91 \\
\hline Cervix uteri (women only) (180) & 17 & 0.68 & 11 & 1.47 & 1 & $0.10^{\star}$ & - & - \\
\hline Ovary (women only) (183) & 64 & 1.10 & - & - & 13 & 0.67 & - & - \\
\hline Prostate (men only) (185) & 486 & 1.00 & 107 & 0.95 & 76 & 0.93 & 25 & 0.93 \\
\hline Testis and other male genital $(186,187)$ & 16 & 1.06 & - & - & - & - & 1 & 0.42 \\
\hline Kidney $(189.0-189.2)$ & 125 & 0.92 & 30 & 1.22 & 32 & 1.14 & 12 & 0.93 \\
\hline Bladder and other urinary $(188,189.3-189.9)$ & 136 & 0.90 & 28 & 1.03 & 23 & 0.84 & 17 & 1.26 \\
\hline Brain and CNS (191-192) & 131 & $0.82^{\star}$ & 21 & $0.64^{\star}$ & 28 & 0.84 & 13 & 0.78 \\
\hline Non-Hodgkin's lymphoma $(200,202)$ & 215 & 0.93 & 49 & 1.14 & 11 & 0.78 & 13 & 0.82 \\
\hline Hodgkin's disease (201) & 28 & 0.93 & 7 & 0.68 & 10 & 1.25 & 4 & 0.73 \\
\hline Multiple myeloma (203) & 119 & 1.01 & 32 & 1.40 & - & - & - & - \\
\hline Leukaemia and aleukaemia (204-208) & 221 & 1.02 & 41 & 0.82 & 42 & 0.98 & 16 & 0.82 \\
\hline Diabetes $(250)$ & 282 & $0.76^{\star}$ & 124 & 1.02 & - & - & 12 & $0.33^{\star}$ \\
\hline All heart disease $(390-398,402,404,410-429)$ & 7400 & $0.86^{\star}$ & 1868 & $1.08^{\star}$ & 1409 & $0.80^{\star}$ & 710 & $0.68^{\star}$ \\
\hline Cerebrovascular disease $(430-438)$ & 1214 & $0.83^{\star}$ & 385 & $0.88^{\star}$ & 170 & $0.61^{\star}$ & 109 & $0.72^{\star}$ \\
\hline Non-malignant respiratory $(460-519)$ & 1492 & $0.74^{\star}$ & 454 & 0.95 & 389 & $1.15^{\star}$ & 107 & $0.78^{\star}$ \\
\hline Cirrhosis of liver (571) & 481 & $0.60^{\star}$ & 94 & 1.01 & 65 & $0.57^{\star}$ & 63 & 0.86 \\
\hline All external causes (800-999) & 1342 & $0.67^{\star}$ & 334 & $0.73^{\star}$ & 293 & $0.80^{\star}$ & 145 & $0.65^{\star}$ \\
\hline Suicides (950-959) & 380 & $0.69^{\star}$ & 90 & 0.83 & 115 & $1.29^{\star}$ & 48 & 0.88 \\
\hline
\end{tabular}

${ }^{\star} \mathrm{p}<0.05$.

$\dagger$ For consistency, all workers and all follow up periods are presented as reported in the original articles.

†Years of follow up.

$§$ Person-years of follow up (mean).

too few for meaningful presentation. There were 12 testicular or male genital cancers among workers exposed to mixed solvents on a routine or intermittent basis, but there was no evidence of a dose response with years of exposure. Internal analyses were also conducted for specific occupations-such as painters-but again the numbers of cancer deaths were too small for meaningful comparisons except for all cancers and lung cancer. For none of the occupations of interest were there significant increases, deficits, or trends for lung cancer or all cancers combined. Similarly, regression analyses considering years worked with potential exposure to asbestos or cutting oils showed no unusual patterns for the 10 cancers evaluated, but again the number of cancer deaths was small for any specific cancer.

\section{Discussion}

This large, systematic epidemiological investigation of the long term mortality experience of aircraft workers showed that rates of cancer and other diseases were not increased. The study is the largest ever conducted of aircraft workers, and yielded findings in accord with previous investigations displayed in table 10 . These epidemiological studies have shown no significant or consistent increases in cancer mortality related to any specific exposure or combination of exposures among aircraft workers. Indeed, similar to our results, the other studies tended to show low risks for can- cer overall and for several specific types of cancer among workers in the industry.

In the present and other investigations of aircraft workers, low rates of death were found for heart disease, cerebrovascular disease, nonmalignant respiratory disease, and all external causes - such as accidents and suicides. These reductions seem due in part to the initial selection into the workforce and the continued employment of healthy people that is often found in occupational studies. ${ }^{10}$ Similar to most other occupational studies, the so called healthy worker eVect among the workers decreased with attained age and time since employment. For occupational cohorts, the healthy worker eVect is unlikely to be a major stumbling block to assessing causal associations, especially for cancers. ${ }^{11}$

As often seen in occupational studies, workers with the shortest duration of employment had somewhat higher SMRs than longer term workers. ${ }^{10}$ The reasons are not entirely clear but may be related to unhealthy lifestyle characteristics and previous illnesses that make it diY cult for short term workers to keep a job. ${ }^{12}$

Detailed mortality evaluation of factory workers, occupational family groups, and specific occupations also failed to show any consistent patterns that might suggest hazardous workplace exposures or circumstances. In the following paragraphs we discuss several exposure-disease relations that we specifically evaluated because of an initial interest. 
CHROMATE AND LUNG CANCER

Hexavalent chromium is classified as a human carcinogen by the International Agency for Research on Cancer (IARC) on the basis of excess lung cancers found in studies of workers involved in chromate and chromate pigment production and in chromium plating industries. ${ }^{6}{ }^{13}$ We found no increased risk of lung cancer among Lockheed Martin workers with potential for chromate exposure. Our findings are similar to those of other recent studies among workers in the aircraft manufacturing industry, ${ }^{14}$ providing little evidence for an increase in lung cancer among workers exposed to chromate compounds. An early proportionate mortality study of aircraft maintenance workers did report an increase in lung cancer among painters, although not electroplaters, but methodological limitations were noted by the authors. ${ }^{15}$ As shown in table 10, lung cancer has not been reported to be increased in subsequent cohort studies of aircraft workers.

Painters at the Lockheed Martin factories had potential for exposure to chromate based paints as well as to various solvents, and occupational exposure as a painter has been classified as carcinogenic. ${ }^{16}$ However, painters were not found to be at significantly increased risk of lung cancer or any other cancer, suggesting that the controlled situations found in aircraft manufacturing diVer from other circumstances in which lung cancer rates have been reported to be increased. ${ }^{16}$ Our investigation also found no excess of lung or laryngeal cancer for workers in occupations which would be expected to have the highest exposure to chromic acid mists (electroplaters and process equipment operators). Further, internal cohort analysis showed no evidence of a dose response, with the relative risk of lung cancer not increasing with increasing years of potential exposure to chromate. Chromate exposure also was not associated with significant increases in any other type of cancer. The consistency of these analyses indicates that chromate compounds as used in these factories have not resulted in adverse health eVects among the working population.

TRICHLOROETHYLENE (TCE)

Except for benzene, no organic solvent is classified as a human carcinogen. ${ }^{7}$ The IARC, however, has concluded that there is limited evidence from human studies that TCE could cause cancers of the liver and non-Hodgkin's lymphoma, ${ }^{7}$ although this evaluation has been questioned. ${ }^{9}$ After the IARC report, two large scale cohort studies of workers exposed to TCE in the aircraft industry were published. ${ }^{34}$ Both, as well as an earlier study of aircraft workers in San Diego, ${ }^{2}$ failed to show a significant excess of any cancer. At the Hill Air Force Base in Utah, workers were involved with the repair and maintenance of aircraft, rather than manufacture, and cumulative exposures to TCE were accordingly greater than at Lockheed Martin factories. ${ }^{3}{ }^{17}$ Also, TCE was used longer, until 1978, at the Hill Air Force Base, and was used as a wipe solvent. Rate ratios for liver cancer and non-Hodgkin's lymphoma were increased overall in the Hill study, but risks were inversely related to cumulative exposure to TCE - that is, workers with the highest exposure were at the lowest risk of liver cancer and non-Hodgkin's lymphoma. At the Hughes Aircraft Company in Arizona, workers exposed to TCE were not at increased risk of liver cancer (six observed $v 6.1$ expected) or nonHodgkin's lymphoma (three observed $v 3.1$ expected), and those in the highest exposure category were at lowest risk for both malignancies. ${ }^{4}$ Among workers in San Diego, deficits of both liver cancer and non-Hodgkin's lymphoma were found. ${ }^{2}$

Our study is consistent with these recent investigations of aircraft workers in that no significant increases of any cancer were associated with exposure to TCE. In fact, workers routinely exposed to TCE on a daily basis were significantly less likely to die of cancer than people in the general population. Liver cancer, highlighted in the IARC report, occurred below expectation among Lockheed Martin workers exposed to TCE, and there was no evidence for a dose response. The SMRs for liver cancer $>1.40$ could be excluded with 95\% confidence. For workers routinely exposed to TCE, the mortality from nonHodgkin's lymphoma was slightly greater than expected (14 v 11.8), and the internal analysis provided limited evidence for a dose response, but neither the overall excess nor the trend was significant. The SMRs $>2.00$ could be excluded with $95 \%$ confidence. The weak relation between TCE and non-Hodgkin's lymphoma among Lockheed Martin workers contrasts with the lack of increased risk and the inverse exposure gradients found for nonHodgkin's lymphoma in both the Hill and Hughes aircraft studies, where exposures to TCE were likely much greater than at Lockheed Martin, suggesting that TCE was not responsible for the slight and nonsignificant increase in non-Hodgkin's lymphoma found in our study.

A link between TCE and kidney cancer has also been postulated based on limited animal evidence, although most epidemiological studies find little or no association. ${ }^{18}$ Similar to other reports within the aircraft industry (table 10), we found no significant associations. Among the factory workers routinely exposed to TCE, seven kidney cancers were recorded compared with 7.1 expected, and internal regression analysis showed no evidence for an increase in risk of kidney cancer associated with years of exposure to TCE. There was ample time for expression of an increased risk of renal (and other) cancers, as exposure to TCE occurred before 1966 and follow up was to the end of 1996 .

Although the Hill Air Force Base study found little evidence to support a causal relation between exposure to TCE and any specific cancer, the authors concluded that further attention might be paid to possible links with breast cancer, multiple myeloma, and non-Hodgkin's lymphoma. ${ }^{3}$ Non-significant increases were also reported for asthma and 
cancers of the bone, oesophagus, colon, and cervix. The Hughes study also reported no consistent associations between TCE and any specific cancer, but noted slight increases for cancers of the bladder, kidney, prostate, and ovary. ${ }^{4}$ We could confirm none of these possible associations. Among the workers most heavily exposed to TCE in our series, there were no significant excess deaths ascribed to multiple myeloma (six observed $v 6.6 \mathrm{ex}-$ pected) or cancers of the breast (seven $v 5.3$ ), bladder (five $v 9.1$ ), prostate (32 $v 31.1$ ) or ovary (one $v 1.7$ ). Increased risks were also not apparent for asthma (one $v 2.2$ ), or cancers of the bone (one $v 0.7$ ), oesophagus (seven $v 8.4$ ), colon (30 $v 28.0$ ), or cervix (zero $v 0.7$ ). Our internal cohort analyses showed no evidence of a dose-response for multiple myeloma, or cancers of the breast, prostate, or oesophagus. Thus, our investigation provides little evidence that exposure to TCE in the aerospace industry has resulted in a measurable increase of any cancer.

PERCHLOROETHYLENE (PCE)

Perchloroethylene, also known as tetrachloroethylene or perc, is a colourless organic compound that has been used as an industrial solvent for $>50$ years. Perchloroethylene replaced TCE at the Lockheed Martin factories in 1966 and was used primarily in vapour degreasing activities. In 1995, the IARC concluded that there is limited evidence in humans for the carcinogenicity of PCE, based on several epidemiological reports of primarily dry cleaning workers, of increased risks of cancers of the oesophagus, bladder, cervix, and nonHodgkin's lymphoma. ${ }^{78}$ Experimental studies of rats exposed to PCE have found leukaemia to be induced. ${ }^{78}$ We identified over 2600 workers routinely exposed to PCE and found no significant increases compared with the general population. Leukaemia (five observed $v 4.6$ expected) and cancers of the oesophagus (six $v$ 4.1 ), cervix (zero $v 0.5$ ), and bladder (two $v$ 2.9) occurred close to or below expectation, and cancer of the liver (seven $v 3.4$ ) was increased but not significantly.

Internal cohort analyses showed no increases in risks with increasing years of exposure to PCE for all cancers combined. The rates of liver cancer and non-Hodgkin's lymphoma were somewhat increased overall and among those with the longest durations of exposure to PCE, but none of the trends or relative risks were significant and the dose-response relations were erratic. Occupations associated with processing had the highest potential for exposure to PCE, but no excesses of liver cancer, non-Hodgkin's lymphoma, or other cancers were found among this group. Air sampling data from 1978 to 1988 indicated relatively low concentrations of PCE that were well below permissible exposure limits.

Possible links have been suggested between consumption of drinking water contaminated with PCE and leukaemia, and cancers of the rectum, lung, bladder, and breast. ${ }^{19-21}$ As noted, we found no significant excess of leukaemia or cancers of the rectum, lung, and bladder, and only four breast cancers were observed $v 3.4$ expected among women routinely exposed to PCE. These null findings are consistent with other studies of aircraft workers (table 10).

\section{MIXED SOLVENTS}

Workers typically were not exposed to single chemicals, but rather to various solvents and substances depending on job activities. To take into account this multiplicity of exposures, a category of mixed solvents was constructed and jobs were ranked as routine, intermittent, or no use of solvents. For the 32000 plus workers with either routine or intermittent exposure to any solvent, there was no significant increase in any cancer, whereas deficits were apparent for several cancers, including buccal cavity, stomach, and brain cancer. Similar patterns of risk were apparent among the workers who routinely used solvents, including TCE and PCE, with deficits also apparent for all cancers and lung cancer. The low risk of brain cancer provides no support for an association with solvents reported in some studies in other industries. ${ }^{22}$ The internal cohort analyses showed no significant dose-response patterns for workers most heavily exposed to mixed solvents.

A significant excess of cancer of the testis or other male genitalia was found among workers with potential for routine exposure to mixed solvents, although the number of cancers was small and risk was unrelated to duration of exposure. An increased risk of cancer of the germ cells of the testis has been reported among workers employed in maintenance and repair of United States navy jets. ${ }^{23}{ }^{24}$ The exposure suspected by the authors of one study was dimethylformamide, an organic solvent used in depotting activities in F4 Phantom jet repair factories during the Vietnam War. Dimethylformamide, however, was not identified as being commonly used at the factories we studied. Furthermore, one of the six male genital cancers among Lockheed Martin workers exposed to solvents was a penile cancer; and only one of the five testicular cancers was likely to be of germ cell origin as all but one case died after the age of 50, an age distribution uncommon for a type of testicular cancer restricted primarily to young adults. ${ }^{25}$ All seven germ cell tumours among F4 Phantom jet workers occurred in men under the age of $47 .{ }^{23}$ After review of employment histories, we found no common occupation or exposure pattern among the Lockheed Martin workers with testicular or other male genital cancer: one worked routinely with PCE, three with chromate, and three were employed for $<5$ years. The causes of testicular cancer are not well understood, ${ }^{25}$ and we do not have a clear explanation for the higher number of male genital cancers, although multiple comparisons made in our analyses might have played a part in producing this significant observation.

Leukaemia was a cancer of initial interest because of analogy with the known increased risks of this cancer in workers exposed to 
benzene, an industrial solvent. ${ }^{26}$ There was no indication that benzene was heavily used at any time at Lockheed Martin factories, although it may have been a constituent of some solvent mixtures. However, there were no significant increases in leukaemia in any of the comparisons made. Organic solvents have also been suggested as a risk factor for glomerular nephropathies and chronic renal failure, ${ }^{27}$ but we found no evidence for increased mortality from non-malignant renal disease among workers routinely exposed to TCE, PCE, or any mixed solvent. A significant $24 \%$ excess of prostate cancer was found among all factory workers employed for $\geqslant 30$ years; but prostate cancer was not associated with any specific occupation or exposure. Internal comparisons also failed to link prostate cancer with increasing years of exposure to any solvent, mixed solvent, or chromate.

\section{ASBESTOS}

Exposure to asbestos seemed to be minimal at the study factories, although it was used in some insulation materials and in the construction of certain aircraft, such as the SR-71. The exposure to asbestos, however, rarely involved high concentrations of free floating fibres. Among the workers with potential exposure to asbestos, there were no significant increases of any cancer. The lung cancer SMR was modestly increased (SMR 1.39) based on 25 cancer deaths. One death due to pleural mesothelioma (ICD-9 163) occurred in a maintenance welder with only 2 months potential exposure to asbestos while at the Lockheed Martin Burbank factory. On review of his work history it was found that he had been employed in several dry dock factories involved with the repair and maintenance of ships in the 1950s where considerable exposure to asbestos was likely. In the entire cohort there were a total of 11 deaths due to pleural cancer by contrast with 6.8 expected (SMR $1.62 ; 95 \%$ CI 0.81 to 2.91 ). Work histories before being employed at Lockheed Martin, systematically recorded on the employment cards, were reviewed and showed potential for previous heavy exposure to asbestos for at least four of these workers-for example, during boiler tendering or work in naval shipyards.

STRENGTHS, LIMITATIONS, AND

METHODOLOGICAL ISSUES

Strengths of the current study include the large size of the worker population, the long follow up, and the comprehensive exposure assessment approach. The cohort is the largest group of aircraft workers ever assembled, and follow up averaged over 20 years per worker and extended up to 37 years. Workers with the longest follow up were employed before 1950 and experienced no increased mortality, although entry into the cohort required each worker to have been employed at some time during or after 1960. Although we did not include all early employees in the current investigation, we did identify and trace a random sample of over 4000 workers who had worked for at least 1 year before ending employment in the 1950s. Their all cause mortality (SMR 0.85) and all cancer mortality (SMR 0.82) were similar to those of workers employed in the 1960s and after. Thus there was no evidence that the early workers at Lockheed Martin factories experienced diVerent mortality patterns from later employees.

Our approach to exposure assessment included reviewing detailed job descriptions, interviewing long term workers, conducting several walkthrough visits of aircraft manufacturing plants, reviewing detailed environmental assessment reports and industrial hygiene surveys, and calling on experience gained in a previous study of aircraft repair workers. ${ }^{17}$ Also, the amount and quality of detailed information on individual work histories is unprecedented for a study of this size. Nevertheless, although we were able to associate exposure from specific chemicals and substances with specific occupations, a study limitation is that the actual level-for example, ppm-of occupational exposure to any substance could not be realistically assigned over the span of more than 6 decades of work histories. Such a limitation would be true of any long term study of aircraft workers where actual measurements of exposure did not begin until the late 1970s and early 1980s. Thus we chose as our measures of exposure the indication that an employee had worked in jobs with high potential for use of the chemical or substance of interest and the duration of work in such jobs. Misclassification of such exposure might aVect our ability to detect variations in risk, but the variety of ways potential exposures were evaluated (by occupation, family groupings, exposure potential, duration of exposure, latency, and calendar year of employment) makes it unlikely that any large increases in risk of disease would have been missed. The absence of consistent patterns across these varied categories supports the conclusion that aircraft workers have not experienced any major increases in mortality from any disease.

Smoking is a potential confounder in occupational mortality studies, although direct information is rarely available. In our investigation, smoking information was available and abstracted for nearly 4000 workers from routine medical history questionnaires and from periodic special questionnaire surveys. Although adjustment for smoking by individual cohort members could not be made from this selected and limited amount of data, qualitative evaluations indicate that factory workers were more likely to smoke than non-factory workers $(33.4 \%$ v $23.1 \%)$ and that female workers smoked as much as their male counterparts (33.6\% v 31.5\%). Smoking prevalences among workers were also higher in the 1980 s than the 1990 s (39.9\% v 28.9\%).

The choice of an external comparison group can influence the magnitude and direction of SMRs. The worker population studied is diverse and consists of every major ethnic classification in relatively large proportions, including Asians, Hispanics, African 
Americans, and American Indians. External comparison, however, could be made only for two broad racial classifications, white and non-white. White workers included Hispanic people and non-whites workers included Asian Americans, African Americans, and American Indians. DiVerences between the observed and the computed expected number of deaths could reflect any diVerences in the ethnic composition between the general population used for comparison and the worker population.

The number of comparisons made in this study was large, and it could be tempting to seek out and discuss only those diseases with significantly or suggestively high (or low) increases. By chance alone, some relative risks or trend lines might be expected to be significant. Thus care was exercised in not attributing increased or reduced risks to specific exposures based on statistical testing alone; rather we considered consistency with other study findings as well as possible methodological biases or confounding. Some of the lowered risks were consistent with the healthy worker eVect, which we have discussed. Other risk estimates are likely to reflect the chance of finding both lower and higher risks when making multiple comparisons. Of the few increased risks, none was consistent across job and chemical exposure groupings.

Our study was based on mortality, with causes of death specified on death certificates. There is some concern about their accuracy, although the inaccuracy of cause of death on death certificates is less for cancer than other causes. ${ }^{28}$ Liver cancer is known as one of the cancers most likely to be misclassified on death certificates, mainly because it is often a metastatic site and distinguishing metastatic lesions from primary cancer is often problematic. The situation for non-Hodgkin's lymphoma is unique with major changes in classification schemes and the application of diagnostic approaches based on immunohistochemistry occurring over the past several decades. Such changes are likely to have influenced the recording of non-Hodgkin's lymphoma on death certificates over time, which conceivably could be somewhat better for workers than for the general population because of more complete medical evaluations. $^{29}$

The multiplicity of available data sets for workers permitted comprehensive quality control checks to assure that the entire population was identified and that mortality searches were of high accuracy. Name, date of birth, social security number, sex, and race were available from Kardex cards, three separate personnel listings, retirement files, and other Lockheed Martin and California state records. This complete and accurate identifying information together with use of multiple sources was instrumental in achieving a high follow up rate for ascertaining vital status, with $<2 \%$ of known deaths with missing causes of death. Further, the use of pension records, Health Care Financing Administration beneficiary files, and Department of Motor Vehicle files confirmed that most of the worker population not found to have died based on mortality searches were in fact alive.

In conclusion, this large scale investigation with nearly complete follow up and access to data on job histories and historical exposure information leads us to conclude that the aircraft workers under study have not experienced significant adverse health eVects as a result of their occupational activities.

We are grateful for the assistance provided by the staV of the Lockheed Martin Corporation, Century Reprographics in Los Angeles, CA, and Westat in Rockville, MD. The advice and guidance provided by our Scientific Advisory Committee, Sir Richard Doll (Oxford University), Dr J Malcolm Harrington (Birmingham University, UK) and Dr Richard R Monson (Harvard University), is gratefully acknowledged. Funding for this research was provided by the Lockheed Martin Corporation.

1 Marsh GM, Youk AO, Stone RA, et al. OCMAP-PLUS: a program for the comprehensive analysis of occupational cohort data. Occup Environ Med 1998;40:351-62.

2 Garabrant D, Held J, Langholz B, et al. Mortality of aircraft manufacturing workers in southern California. Am $\mathcal{F}$ Ind Med 1988;13:683-93.

3 Blair A, Hartge P, Stewart PA, et al. Mortality and cancer incidence of aircraft maintenance workers exposed to trichloroethylene and other organic solvents and chemicals: extended follow up. Occup Environ Med 1998;55:161-71.

4 Morgan RW, Kelsh MA, Zhao K, et al. Mortality of aerospace workers exposed to trichloroethylene. Epidemiology 1998;9:424-31.

5 Preston DL, Lubin JH. EPICURE: risk regression and data analysis software. Seattle, WA: HiroSoft, 1993.

6 International Agency for Research on Cancer. IARC monographs on the evaluation of carcinogenic risks to humans. Vol 49. Chromium, nickel and welding. Lyon, France: IARC, 1990.

7 International Agency for Research on Cancer. IARC monographs on the evaluation of carcinogenic risks to humans. Vol 63. Dry cleaning, some chlorinated solvents and other industrial chemicals. Lyon, France: IARC, 1995.

8 Weiss NS. Cancer in relation to occupational exposure to perchloroethylene. Cancer Causes Control 1995;6:257-66.

9 Weiss NS. Cancer in relation to occupational exposure to trichloroethylene. Occup Environ Med 1996;53:1-5.

10 Checkoway H, Pearce NE, Crawford-Brown DJ, eds. Research methods in occupational epidemiology. New York: Oxford University Press, 1989.

11 Howe GR, Chiarelli AM, Lindsay JP. Components and modifiers of the healthy worker eVect: evidence from three occupational cohorts and implications for industrial compensation. Am f Epidemiol 1988;128:1364-75.

compensation. Am f Epidemiol 1988;128:1364-75.
12 Kolstad HA, Olsen J. Why do short term workers have high mortality? Am f Epidemiol 1999;149:347-52.

13 Sorahan T, Burges DC, Hamilton L, et al. Lung cancer Sorahan T, Burges DC, Hamilton L, et al. Lung cancer
mortality in nickel/chromium platers, 1946-95. Occup Environ Med 1998;55:236-42.

14 Alexander BH, Checkoway H, Wechsler L, et al. Lung cancer in chromate-exposed aerospace workers. F Occup Environ Med 1996;38:1253-8.

15 Dalager NA, Mason TJ, Fraumeni JF Jr, et al. Cancer mortality among workers exposed to zinc chromate paints. $\mathcal{F}$ Occup Med 1980;22:25-9.

16 International Agency for Research on Cancer. IARC monographs on the evaluation of carcinogenic risks to humans. Vol 47. Some organic solvents, resin monomers and related compounds, pigments and occupational exposures in paint manufacture and painting. Lyon, France: IARC, 1989.

17 Stewart PA, Lee JS, Marano DE, et al. Retrospective cohort mortality study of workers at an aircraft maintenance facilmortality study of workers at an aircraft maintenance facil-
ity. II Exposures and their assessment. Br f Ind Med 1991; ity. II Exp:531-7.

18 McLaughlin JK, Blot WJ. A critical review of epidemiology studies of trichloroethylene and perchloroethylene and risk of renal-cell cancer. Int Arch Occup Environ Health 1997;70:222-31

19 Aschengrau A, OzonoV D, Paulu C, et al. Cancer risk and tetrachloroethylene-contaminated drinking water in Massachusetts. Arch Environ Health 1993;48:284-92.

20 Aschengrau A, Paulu C, OzonoV D. Tetrachloroethylenecontaminated drinking water and the risk of breast cancer. Environ Health Perspect 1998;106 (suppl 4):947-53.

21 Paulu C, Aschengrau A, OzonoV D. Tetrachoroethylenecontaminated drinking water in Massachusetts and the risk of colon-rectum, lung, and other cancers. Environ Health Perspect 1999;107:265-71.

22 Inskip PD, Linet MS, Heineman EF. Etiology of brain Inskip PD, Linet MS, Heineman EF. Etiology
tumors in adults. Epidemiol Rev 1995; 17:382-414.

23 Ducatman AM, Conwill DE, Drawl J. Germ cell tumors of the testicle among aircraft repairmen. F Urol 1986;136: $834-6$. 
24 Garland FC, Gorham ED, Garland CF, et al. Testicular cancer in US Navy personnel. Am f Epidemiol 1988;127: cancer

25 Schottenfeld D. Testicular cancer. In: Schottenfeld D, Fraumeni JF Jr, eds. Cancer epidemiology and prevention, 2nd ed. New York: Oxford University Press, 1996:1207-19.

26 Hayes RB, Yin SN, Dosemeci M, et al. Benzene and the dose-related incidence of hematologic neoplasms in China. Chinese Academy of Preventive Medicine: National Cancer Institute Benzene Study Group. $\mathcal{F}$ Natl Cancer Inst 1997;89:1065-71.
27 Stengel B, Cenee S, Limasset JC, et al. Organic solvent exposure may increase the risk of glomerular nephropathies with chronic renal failure. Int 7 Epidemiol 1995;24: 427-34

8 Percy C, Stanek E, Gloeckler L. Accuracy of cancer death certificates and its eVect on cancer mortality statistics. $\mathrm{Am}$ f Public Health 1981;71:242-50.

29 Greenwald P, Friedlander BR, Lawrence CE, et al. Diagnostic sensitivity bias: an epidemiologic explanation for an apparent brain tumor excess. Occup Med 1981;23: $690-4$. 